\title{
Rodent models of heart failure: an updated review
}

\author{
A. C. Gomes • I. Falcão-Pires • A. L. Pires • \\ C. Brás-Silva $\cdot$ A. F. Leite-Moreira
}

(C) Springer Science+Business Media, LLC 2012

\begin{abstract}
Heart failure (HF) is one of the major health and economic burdens worldwide, and its prevalence is continuously increasing. The study of HF requires reliable animal models to study the chronic changes and pharmacologic interventions in myocardial structure and function and to follow its progression toward HF. Indeed, during the past 40 years, basic and translational scientists have used small animal models to understand the pathophysiology of $\mathrm{HF}$ and find more efficient ways of preventing and managing patients suffering from congestive HF (CHF). Each species and each animal model has advantages and disadvantages, and the choice of one model over another should take them into account for a good experimental design. The aim of this review is to describe and highlight the advantages and drawbacks of some commonly used HF rodents models, including both non-genetically and genetically engineered models, with a specific subchapter concerning diastolic HF models.
\end{abstract}

Keywords Animal models - Rodents - Heart failure · Diabetes mellitus $\cdot$ Cardiovascular research

\section{Introduction}

Heart failure (HF) is a complex syndrome in which patients should present the following characteristics: symptoms of $\mathrm{HF}$, signs of fluid retention and objective evidence of an

A. C. Gomes · I. Falcão-Pires · A. L. Pires · C. Brás-Silva ·

A. F. Leite-Moreira $(\square)$

Department of Physiology and Cardiothoracic Surgery, Faculty

of Medicine, University of Porto, Alameda Professor Hernâni

Monteiro, 4200-319 Porto, Portugal

e-mail: amoreira@med.up.pt abnormality of the cardiac structure or function at rest [53]. It is often divided in two distinct entities, namely systolic heart failure (SHF) and diastolic heart failure (DHF) or, in alternative, HF with reduced ejection fraction and HF with preserved ejection fraction, respectively. Despite the hot controversy on the definition of each entity, SHF is characterized by an inability of the myocardium to contract and eject blood, while DHF refers to a disturbance in accommodating blood volume during diastole at low filling pressures, due to impaired ventricular relaxation (primarily affecting early diastole) or increased myocardial stiffness (primarily affecting late diastole) [152]. Besides defective myocardial relaxation, the mechanisms underlying DHF include abnormal extracellular matrix dynamics and altered myocyte cytoskeleton, which could interfere with the passive properties of the ventricular wall [152].

The great majority of animal models have been developed for SHF. Besides being rather difficult to replicate pure DHF in animal models, these are also more demanding and time-consuming than SHF. Therefore, not surprisingly most HF models developed so far represent SHF.

\section{Non-genetically engineered rodent models}

Pharmacologically induced cardiomyopathy

\section{Doxorubicin}

Doxorubicin (adriamycin, DOX) is an anthracycline widely used in cytostatic treatments. One of the major long-term consequences of DOX therapy is the development of cardiomyopathy and ultimately CHF in humans as in experimental animals. Therefore, understanding the pathogenesis 
of cardiotoxic cardiomyopathy is essential to the development of new measures to prevent cardiotoxicity associated with antineoplastic therapies. DOX causes a dose-dependent cardiotoxicity and thus has been used to induce HF in various animal species [21, 37, 291, 293].

DOX administration once a week for 6 weeks or on alternate days for 2 weeks has been shown to induce cardiomyopathy and HF [51, 168, 284]. Interestingly, a single dose of DOX has been shown to induce significant left ventricular (LV) dysfunction in mice after 5 days [189]. This drug is usually administered by intravenous or intracoronary injection. The latter allows delivery of DOX at a smaller dose to induce HF without systemic toxicity [203].

DOX-induced cardiomyopathy is characterized by ventricular wall thinning and dilatation, and depressed systolic and diastolic function $[22,50,168,291]$ accompanied by fluid retention and by neurohumoral activation [8]. At the cardiac muscle level, DOX promotes intrinsic contractile dysfunction and reduced contractile reserve [21, 22, 50]. Furthermore, DOX impairs vascular [208] as well as endocardial [21] endothelial function and [27, 151, 287] induces inflammatory reactions in the heart, leading to thrombosis in the atria and myocarditis [27, 75, 78, 293].

Multiple pathways of anthracycline-induced cardiac cellular injury have been proposed such as the release of cardiotoxic substances, which subsequently accumulate in cardiomyocytes [185], the generation of free radical, lipid peroxidation, and suppression of DNA, RNA and protein synthesis $[255,276]$. Other studies suggest that cardiotoxicity pathways include abnormalities in $\mathrm{Ca}^{2+}$ handling [50, 54, 285]; induction of mitochondrial DNA lesions [149]; degradation of myofilamental and cytoskeletal proteins, including titin [160] and dystrophin [40]; interference with various pro-survival kinases [224]; and changes in adrenergic and adenylate cyclase function [33, 74]. These examples of a much larger set of proposed cardiotoxic mechanisms are not mutually exclusive: they may each contribute to cardiac cell damage, ultimately leading to myocyte death, by either necrosis or apoptosis [254]. Additionally, it was recently demonstrated that DOX cardiomyopathy can be also mediated by depletion of the cardiac stem cell pool and rescued by restoration of progenitor cell function [50].

Spontaneous hypertensive rats (SHR) are more sensitive to the toxic effects of DOX [98], probably because of the low free radical-scavenging ability of their myocardium [122].

DOX model has a short time course of induction of HF and also the advantages of being technically simple, reproducible, non-invasive and economical. Additionally, it can be used in several animal species to promote either chronic or acute HF [203]. The main limitations of this model are related to the variable degree of ventricular dysfunction and the high incidence of arrhythmias that contribute to the high mortality rate. Anthracycline administration also has undesirable bone marrow, gastrointestinal and renal toxicities that can however be eliminated by the intracoronary injection of the drug $[8,203]$.

\section{Homocysteine}

Hyperhomocysteinemia has been identified as a causative factor of cardiac stress and dysfunction in both spontaneous hypertensive and normotensive rats [129, 130]. In rats, supplementation of diet with homocysteine for 10 weeks produces hyperhomocysteinemia and consequently ventricular dysfunction with compromised systolic and diastolic function $[52,130]$. The main factors involved in the development of $\mathrm{HF}$ are oxidative stress and inflammatory mediators [129].

\section{Isoproterenol}

Excessive doses of catecholamines produce diffuse myocardial destruction with cardiomyocyte necrosis and extensive fibrosis in both animals and humans [219, 220, 292]. The mechanism underlying myocardial damage is likely related to an imbalance between oxygen supply versus demand due to myocardial hyperactivity [62]. In mice, infusion of isoproterenol for 7 days has been shown to induce cardiac dysfunction [216]. In rats, subcutaneous administration of isoproterenol for 3 days leads to a dosedependent impairment of cardiac function and neurohumoral activation [88, 325], with cardiomyocyte necrosis and extensive LV hypertrophy and dilation and after 2 and 12 weeks, respectively [92, 324]. However, isoproterenol administration before ischemia exerts a cardioprotective effect in rats [92]. The advantages of this model are its technical simplicity and excellent reproducibility in association with a satisfactory low mortality. Nonetheless, it seems not suitable for inducing an overt state of $\mathrm{CHF}$ because higher doses of catecholamines can increase the mortality rate up to $80 \%$ [88].

\section{Monocrotaline}

Monocrotaline (MCT) is a plant toxin derived from Crotalaria spectabilis that can be administered by intraperitoneal, subcutaneous or intravenous injection to induce right ventricular dysfunction and HF within 4-6 weeks [30, 299]. Current hypotheses of the pathogenesis of MCTinduced pneumotoxicity suggest that MCT is transformed in a bioactive pyrrole metabolite in the liver and is then transported by red blood cells to the lung, where it initiates endothelial injury. The metabolite has a half-life of $\sim 3 \mathrm{~s}$ in aqueous media and primarily affects the pulmonary 
vascular bed as lungs are the first major vascular bed after the liver [230]. Nonetheless, MCT can injury other structures such as liver [135] or kidney [262]. In the pulmonary vasculature, MCT induces perivascular inflammation, platelet activation and endothelial dysfunction, generally leading to increased pulmonary arterial pressure. These changes are accompanied by increase in RV systolic and diastolic pressures, hypertrophy and ultimately HF [99, 310]. Besides inducing HF, MCT is a simple model which, at an earlier phase, shares some similarities with human pulmonary hypertension.

\section{Myocardial infarction-induced HF}

Since ischemic heart disease is the most important cause of human HF, coronary artery occlusion is the most common method of inducing acute myocardial damage in animal models. Ligation of the left anterior descending (LAD) coronary artery or one of its branches remains the most preferred and acceptable method of inducing regional injury and subsequent HF in rodents [10, 85], as well as to gain further insight into pathophysiology of post-myocardial infarction (MI) cardiac remodeling [12, 223]. The mechanisms responsible for cardiac remodeling are mostly related to changes in extracellular matrix of the remaining overloaded myocardium and neurohumoral activation [72, 156, 234].

Surviving mice gradually develop HF within the 4 weeks following the surgical procedure [76, 155, 158]. In rats, a significant decrease up to $25 \%$ in cardiac output is observed 8 weeks after LAD ligation [115]. The infarct size varies significantly (between 10 and 45\%) and is directly related to the degree of $\mathrm{LV}$ function impairment [228], influencing the time course of CHF development [10]. Generally, the infarct extension needs to affect at least $30 \%$ of the LV mass in order to present the typical characteristics of CHF and to induce considerable increases in the molecular markers of hypertrophy [10]. Age also exerts a noteworthy effect on the time course of CHF development, with young animals tolerating well LAD ligation without CHF signs, in spite of the larger infarct size [85]. Some recent studies showed that female mice undergo less extensive ventricular remodeling, suggesting the influence of sex hormones as a putative explanation for gender differences [315].

In both mice and rats, mortality ranges between 35 and $50 \%$ and occurs within the first hour after MI due to ventricular fibrillation and severe acute HF [79, 144]. Furthermore, in rats, it seems to be strain dependent with Lewis inbred rats surviving more than Sprague-Dawley rats [164].

Contrary to the clinical situation, in which the patient has progressive non-occlusive coronary artery obstruction, myocardial infarct in this model is due to the sudden occlusion of a normal coronary artery. Therefore, efforts have been made to create a model of chronic myocardial ischemia, more similar to the clinical reality. Indeed, a mice model of hyperlipidemia and atherosclerosis with multiple infarction and CHF has been described. However, those high-density lipoprotein receptor SR-B1 and apolipoprotein-E double knockout mice survive only few weeks after birth limiting their use in HF research [23].

Protocols of temporary LAD occlusion have been developed to reproduce human ischemia-reperfusion injury. This model has confirmed the benefits of reperfusion since infarct size was found to be significantly lower than after permanent occlusion of the coronary artery. However, they also revealed the diversity of results as a consequence of mouse left coronary anatomic high variability [187].

The procedure was further modified to analyze ischemic preconditioning of the heart. In this method, LAD is repeatedly occluded to subject the heart to several rounds of brief ischemia and reperfusion before permanent occlusion. Molecular analyses identified various ischemiainduced genes that confer tolerance to subsequent ischemic event [311].

The cost and simplicity confer important advantages to LAD ligation. On the other hand, rat differs from human in terms of electrophysiology, coronary circulation, cardiac protein isoforms and time course of MI evolution. In fact, available data point to a faster onset of healing and termination processes in rats [142], which mean results must be interpreted with caution.

An alternative model of MI was cryoinfarction, which induces a series of cryoinjuries in the epicardium of mice and rats [245]. However, it has not caught the interest of the scientific community, and thus, it is no longer used.

\section{Myocarditis-induced HF}

Viral myocarditis is a common cause of dilated cardiomyopathy and HF. The coxsackie-B3 virus (CB3) and the encephalomyocarditis virus (EMCV) have been used to induce myocarditis in rodents [102, 213, 318]. EMCV infection can lead to myocyte necrosis and significant biventricular dilation during the phase of viremia, while typical signs of CHF appear after 7-14 days of virus inoculation $[68,177,213]$. This model is limited to Balb/c and DBA/2 mice because other mouse strains are resistant to virus infection [306]. Virus inoculation in genetic engineered mice has been shedding light on the molecules involved in the pathogenesis of viral myocarditis. Indeed, the administration of an exogenous antitumor necrosis factor- $\alpha$ (anti-TNF- $\alpha$ ) antibody reduced myocardial lesion and improved survival, mitigating the effect of the 
observed increase in TNF- $\alpha$ expression [178]. A retrovirus model of encephalitis and myocarditis in mice showed that nuclear factor-kB activation confers protection against virally mediated apoptosis and its expression is preserved in the presence of interferon- $\beta$. The absence of any of these molecules in the myocardium leads to striking viral infection and cell death [214]. Transgenic knockout models of components of the immune system have provided interesting insights in the pathogenesis of viral myocarditis [163].

Another pathogenic agent capable of causing myocarditis and dilated cardiomyopathy is the protozoan parasite Trypanosoma cruzi, which causes Chagas disease, a major form of HF in Latin America [46]. The infection causes generalized vascular inflammation, which stimulates the production of endothelin-1 and thromboxane-A2, further enhancing coronary vasospasm and myocardial ischemia [35].

Autoimmune myocarditis has been induced by an immunization process with different intracellular antigens. In rats, hemodynamic deterioration and myocarditis have been reported after 3 weeks of immunization with cardiac $\alpha$-myosin or $\alpha$-myosin peptides [173, 305]. This was associated with increased expression and activity of inducible nitric oxide synthase (iNOS) and an inhibitor of that enzyme effectively attenuated the histopathologic changes, thus pointing to a relevant pathophysiologic role of nitric oxide (NO) [103, 104]. In mice, immunization with a monoclonal anti-dog SERCA2a antibody caused myocarditis [93].

Immunization of mice with recombinant murine cardiac troponin I (mcTnI) resulted in myocardial deposition and elevated serum levels of anti-mcTnI autoantibodies, accompanied by myocardial inflammation (both humoral and cellular immune response), cardiac dilatation, contractile failure and increased mortality rate [83].

Systemic hypertension-induced HF

\section{Spontaneously hypertensive rats (SHR)}

Systemic hypertension is another relevant factor in human CHF. Spontaneous hypertension is a natural model of pressure overload, in which systemic hypertension leads to HF with aging. Hypertensive vascular lesions appear within 6-7 weeks, being more severe in males than in females. For the first 12 months, the hypertrophy is compensated and contractility is preserved, but after 18-24 months, there is overt CHF characterized by fibrosis, LV dilation and reduced systolic function [13, 100, 226]. These structural and functional changes occur in tandem with a marked raise in cytokine levels such as TNF- $\alpha$ and interleukin-6 [223]. Transition to failure has been suggested to depend on significant alterations in the expression of genes encoding extracellular matrix proteins, oxidative stress and increased apoptosis of myocytes $[1,13$, $15,157,273]$. The gradual onset of hypertension with aging makes this model suitable for studying the transition from hypertrophy to $\mathrm{CHF}$ and for reproducing hypertension-induced CHF in humans [194]. It has the advantage of avoiding the complications associated with surgical or pharmacologic interventions, while mimicking the changes found in human essential hypertension [16, 19]. Nonetheless, the long period required for developing $\mathrm{CHF}$ poses a great limitation, making it a time-consuming and consequently an expensive model. Additionally, this model has other two relevant drawbacks, namely the absence of an appropriate control and the complexity of the genetic mutations, which have affected not only blood pressure but many other regulatory systems as well.

The SHR stroke prone (SHR-SP) is a further developed substrain with even higher levels of blood pressure and a strong tendency to die from stroke [319].

\section{Spontaneously hypertensive HF-prone rats (SHHF)}

Spontaneous hypertensive rats carry the facp corpulent gene, which encodes a defective leptin gene, and therefore, they develop obesity and HF [41, 188]. The time for the development of HF depends on facp gene dosage and gender (male animals are more prone to HF than females [96]) but, in general, SHHF rats present HF earlier than the SHR strain, with loss of cardiac function starting at the age of 15 months [100]. These animals present alterations in the renin-angiotensin-aldosterone system (RAAS) and also in calcium metabolism [82, 107, 188, 222]. The greatest advantage of this strain is the possibility of studying drug interventions in an extended range of cardiovascular risk factors like obesity, diabetes and renal dysfunction [259].

\section{Dahl-salt-sensitive rats}

This is a mutant strain of Sprague-Dawley rats that are characterized by hypersensitivity to sodium intake [48]. When placed on a high-salt diet from the 6th week of age, they develop concentric LV hypertrophy without chamber dilation around the 11th week and decompensate HF with marked ventricular dilation between the 15 th and the 20th week [119, 139]. Failure is associated with reduced myocardial performance as evidenced by the lower performance of muscle strip preparations and the short lifetime of failing rats [119]. Diastolic dysfunction, as well as increased LV endothelin-1 production, collagen accumulation and even survival could be improved more effectively by a combination of angiotensin receptor blockers 
and angiotensin-converting-enzyme (ACE) inhibitors than either agent alone [137].

Interestingly, it has been shown that introducing highsalt diet at 7 or 8 weeks of age can result in distinct HF phenotypes. Indeed, the 7-week starting rats showed a steep elevation in blood pressure and progressive LV hypertrophy, falling into overt DHF at approximately 19 weeks. On the other hand, the 8-week starting rats showed a gradual rise in blood pressure and less progressive LV hypertrophy, developing SHF at approximately 26 weeks. Therefore, these two different models of overt HF may be useful as models of isolated DHF and SHF based on the same hypertensive heart disease, which could be relevant to the pathophysiologic and molecular characterization of each HF subtype [55]. Another report found that the development of HF was dissociated from changes in passive diastolic and active systolic properties, suggesting that volume overload plays an important pathophysiologic role in the development of HF despite preserved overall ventricular pump function in this model of chronic hypertension [139].

This model is suitable to study the transition from compensated hypertrophy to failure. Moreover, it is often used to identify the role of several pathways and molecular mechanisms like oxidative stress, extracellular matrix degradation [289], calcium handling impairment [253] as well as redox-regulated transcription factors [116] and apoptotic factors activation [320].

\section{DOCA-salt rats}

The deoxycorticosterone acetate (DOCA) salt-induced model of hypertension is a typical representative of pharmacologically induced hypertension. A very high subcutaneous dose of DOCA is required to induce hypertension in rats [268]. Isotonic saline is the sole drinking fluid, which hastens and aggravates progression to hypertension [280]. Despite being salt-dependent in its initiation, this model frequently needs surgical reduction of renal mass or unilateral nephrectomy. DOCA-salt hypertension is a low renin and volume-overloaded form of hypertension. The combination of DOCA-salt and unilateral nephrectomy results in hypertension, renal hypertrophy, nephrosclerosis, cardiac hypertrophy and myocardial and perivascular fibrosis within 4-5 weeks of chronic treatment [89, 215].

The pathophysiologic mechanisms underlying the development and maintenance of DOCA-salt hypertension include increased levels of arginine vasopressin [120], angiotensin-II/aldosterone [300, 313], endothelin [179, 204, 258, 302] and oxidative stress [154, 175], excessive activation of the sympathetic nervous system [132] and nitric oxide synthase (NOS) uncoupling due to oxidative depletion of its cofactor tetrahydrobiopterin (BH4) [274]. Indeed, both inhibition of the angiotensin-aldosterone system and endothelin receptor blockade have been shown to prevent cardiac remodeling, even without concomitantly reducing arterial blood pressure [89, 257]. Of notice, PPAR$\alpha$ activation has also a beneficial effect on myocardial fibrosis and prevented diastolic dysfunction in DOCA-salt rats by modulation of NF- $\kappa \mathrm{B}$ inflammatory pathway [215]. Nonetheless, the cardiac consequences are minimal during the development of DOCA-salt hypertension-induced hypertrophy [29]. This is in contrast to the decreased responses reported in other rat models of cardiac hypertrophy and in the failing human heart. Therefore, hypertrophy in hearts of DOCA-salt hypertensive rats does not produce similar changes to the failing human heart [29].

Of notice, a group recently published a mouse model that combines a surgical intervention to induce pressure overload, namely transverse aortic constriction (TAC), with DOCA administration, in the setting of normal-salt diet. Compared with TAC mice, TAC plus DOCA mice had similarly normal LV systolic pressure and fractional shortening but more hypertrophy, fibrosis and diastolic dysfunction with increased lung weights, consistent with HF with preserved ejection fraction. There was progressive activation of markers of oxidative stress but no evidence of classic mineralocorticoid receptor-dependent gene transcription. Therefore, they suggest that pressure-overload hypertrophy sensitizes the heart to mineralocorticoid excess, promoting the transition to DHF without activation of the classic mineralocorticoid receptor-dependent gene transcription.

The major limitations of the DOCA-salt model are (1) the need to employ a large amount of drug, (2) the requirement for surgical reduction of renal mass and (3) the dependence on a strictly controlled ingestion of a high $\mathrm{NaCl}$ dose. On the other hand, its chief advantage is the potential to investigate the role of sodium in the developmental stages of hypertension.

\section{K1C rat}

Since 1934, when Goldblatt and his co-workers induced an elevation of blood pressure by partial constriction of the renal artery of the dog [81], many successful models of renal-induced experimental hypertension have been developed in rats. In general, the procedure includes twokidney Goldblatt hypertension (constriction of one renal artery while the contralateral kidney is left intact) and onekidney Goldblatt hypertension (one renal artery is constricted and the contralateral kidney is removed) [280]. Clipping one renal artery, while leaving the contralateral kidney untouched, induces systemic hypertension and LV concentric remodeling within 8 weeks [131]. Histologic studies revealed extensive LV fibrosis, while echocardiography and hemodynamic data consistently shown diastolic dysfunction [131]. Indeed, inhibition of matrix 
Fig. 1 Timeline progression of transverse aortic constriction: comparison between mice and rat

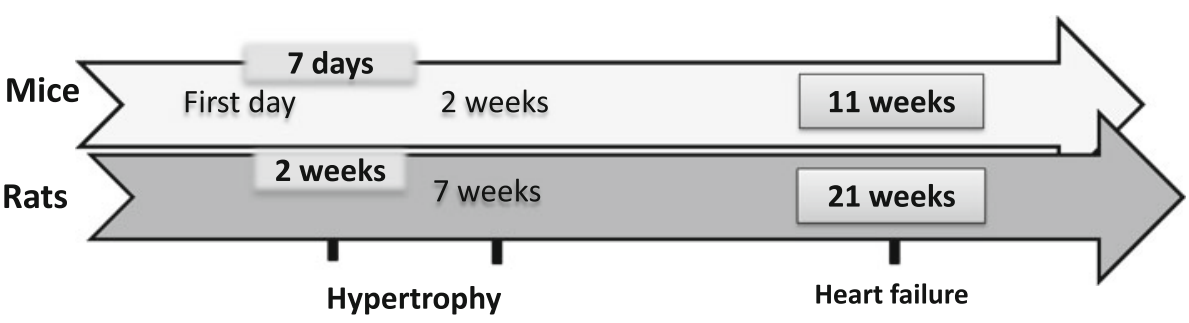

metalloproteinase activity in these hypertrophic hearts has been shown to provide beneficial effects in terms of structure and function [237]. At cellular level, several changes in the energy metabolism, actin-myosin crossbridge cycle and protein expression were identified in renovascular hypertensive rats [131]. In addition, the paramount role of activation of the RAAS [73, 150] and the sympathetic nervous system [32, 270] has been thoroughly studied. In the one-kidney model, no compensatory increase in sodium and water excretion can occur, and hence, fluid volume is retained, which means this model is thus a sodium-fluid volume-dependent model. Therefore, it would advantageous for studying the role of volume expansion in the development of hypertension [11]. During the early developmental stage, when the clip is removed, arterial blood pressure returns to normal in both models, suggesting that renovascular hypertension is both reversible and reproducible [147].

\section{Pressure-overload-induced HF}

Aortic constriction (banding) is a well-established surgical technique for induction of LV chronic pressure overload and hypertrophy in rodents. The banding initially imposes little or no restriction to aortic flow but gradually, as the animal grows, the relative severity of the constriction increases, resulting in cardiac hypertrophy. Aortic banding in several positions has been used to mechanically reproduce the cardiac consequences of aortic stenosis, systemic hypertension and coarctation of the aorta $[111,138,203$, 240, 279]. The constriction can be thoracic, either close to the origin of the aorta, ascending aortic constriction (AAC), or in the aortic arch between the first and second trunks and named transverse aortic constriction (TAC). Alternatively, the constriction can be performed in abdominal aorta, either below or above the renal arteries, the latter inducing hypertension by renal hypoperfusion and concomitantly LV hypertrophy [34]. The anatomic location of the constriction is the main responsible for the differences between these models. In this context, AAC is generally used to study the effects of early insult due to pressure overload, while TAC and suprarenal aortic constriction display a more gradual rise of pressure, progression toward hypertrophy and HF [16].
The timeline of disease progression depends on the selected species, age or gender, with mice subjected to TAC presenting LV hypertrophy as early as 7 days [294] and decompensate HF at 4 weeks [153], while rats present slower progression [16], as illustrated in Fig. 1. For instance, in weanling rats $[70,263,309,316]$, a TAC surgery that reduces $50 \%$ of the aorta diameter creates a systolic pressure gradient of $\sim 50-60 \mathrm{mmHg}$ between the aorta and the LV, inducing clear echocardiographic evidence of LV hypertrophy, and increases left atrial pressure around the 8th week [162]. After 18-20 weeks of compensated LV hypertrophy, a subgroup of animals eventually decreases LV systolic pressure, accompanied by increased LV volume, reduced ejection fraction and clinical signs of overt CHF [309]. Moreover, molecular changes have been reported with increased expression of $\beta$-myosin heavy chain, atrial natriuretic peptide (ANP), interleukin-1, interleukin- 6 and TNF- $\alpha$ [200]. On the other hand, the failing myocardium exhibits a reduced expression of SERCA2a when compared to non-failing hypertrophied heart, which suggested that decreased levels of SERCA2a could be a marker of transition from compensatory hypertrophy to failure in these animals [70].

Abdominal aortic banding in rats causes an initial increase in contractility due to the compensatory activation of the sympathetic nervous system [25] but after 8 weeks, systolic and diastolic dysfunction as well as concentric hypertrophy are evident [34, 67]. In mice, suprarenal abdominal aortic banding causes cardiac hypertrophy within 4 weeks as a compensatory response, which eventually leads to CHF after 15-21 weeks depending on the degree of constriction as well as animal age, gender and weight $[94,312]$. Changes in NO pathway are believed to play an important role in the pressure-overloaded heart and pathologic cardiac remodeling. In fact, reports showed that phosphodiesterase-5 (PDE5) inhibitor sildenafil reduces LV hypertrophy and dilation in the mouse TAC model [223, 290]. However, the most promising therapeutic approach is represented by a new neutral sugar organic nitrate, LA-419, the thiol group of which seems to protect NO from degradation, thereby increasing its bioavailability. In the aortic stenosis model, LA-419 has been found to restore the complete NO signaling cascade and reduce LV remodeling, but without restoring the original pressure 
gradient, indicating a possible direct antiproliferative effect [243]. Additionally, the exogenous administration of the NOS cofactor BH4 has been shown to reduce LV hypertrophy, fibrosis and cardiac dysfunction in mice with pre-established pressure overload. In this setting, BH4 recoupled endothelial NOS, with subsequent reduction of NOS-dependent oxidative stress and reversal of maladaptive remodeling [195, 196].

Among the major advantages that these banding models share compared to other hypertensive or HF models is the ability to manipulate the degree of pressure overload by changing the constriction severity [197]. Concerning the thoracic aorta constrictions, the main advantage is the similarities to human HF progression, especially to aortic stenosis patients. Accordingly, it is characterized by initial compensatory phase, with concentric LV hypertrophy followed by an enlargement of cardiac chambers associated with a further deterioration of LV function [16]. Another advantage is the extensive information regarding TAC model: it was first described in 1994 by Rockman [240], and it has been extensively used since then, especially in mice either by traditional thoracotomy approach [67, 239] or by minimally invasive aortic banding through a small incision in the proximal sternum [111]. Finally, this method permits the quantification of the pressure gradient across the aortic constriction and the stratification of LV hypertrophy [223]. However, the rat TAC model has several drawbacks such as prolong duration of the protocols (Fig. 1), inter-individual variability in the response to pressure overload [198] and high proportion of debanding due to internalization of the constriction knot [171]. These two last disadvantages require the use of large experimental groups and the use of accessory methods for visualization of the constriction integrity and progression of disease, such as echocardiography. Both AAC and TAC models have a common disadvantage resultant from the complex surgical method and equipment necessary for open-chest microsurgery. The lack of such an extended learning curve is the major advantage of abdominal constriction model, alongside with the low mortality rate associated with banding (10\%) [70]. Activation of RAAS might however limit the use of abdominal aorta constriction in some studies [241]. Moreover, decrease of LV relaxation rates makes such models valuable for the evaluation of diastolic dysfunction, which is an important factor in the progression of LV failure [69]. In addition, the stimulus for $\mathrm{HF}$ is gradual in onset as is the progression from compensated hypertrophy to HF in humans, thus making it clinically more relevant. Recently, a minimally invasive murine model of TAC debanding was described, in which it is possible to remove the band up to 4 weeks later through the same suprasternal incision [278]. This reversible model of pressure overload turned out to be an interesting model to study the molecular mechanisms involved in LV reverse remodeling.

\section{Volume-overload-induced HF}

Arteriovenous shunts have been used to induce volume overload and consequently dilated cardiomyopathy and HF in rodents. Femoral artery to femoral vein fistulas lead to $\mathrm{HF}$, but present a reported mortality above $25 \%$ in all studies [217]. The more recent aortocaval shunt is a relatively simpler and faster alternative to induce HF with good survival rates and no need to perform thoracotomy $[28,77$, 231]. In rats, significant cardiac hypertrophy develops 4 weeks after shunt induction, with compromised LV contractility and increased end-diastolic pressure [256]. Severe volume overload from a large aortocaval fistula initially leads to depressed LV function followed by a compensatory hypertrophy and near normal function at 4 weeks $[165,307]$. Decompensated hypertrophy or CHF develops between 8 and 16 weeks after the intervention and is characterized by a decline in systolic and diastolic function $[34,308]$ and a shift between myosin heavy chain isoforms expression [307]. Nonetheless, shunt closure has been reported in $7 \%$ of the cases, which means that it is necessary to confirm the patency of the shunt at the end of investigation. Of note that, not only the duration, but also the size of the shunt will determine the onset and severity of CHF in rats, with elevation of LV end-diastolic pressure reported only in the overt CHF group caused by a large shunt for a minimum period of 4 weeks [148]. This procedure has the advantage of being fast and usually well tolerated, despite the limitation of requiring a laparotomy.

Another procedure used to induce volume overload in rats is aortic valve regurgitation, in which an aortic valve cusp is punctured [56, 207].

The neurohumoral activation of volume-overload models includes local activation of RAAS, which is associated with depressed myocardial function [211]. Recent reports found that ANP expression is a more sensitive marker of volume overload than pressure overload [36]. In addition, long-term overexpression of SERCA2a in this animal model can preserve systolic function and potentially prevent diastolic dysfunction and LV remodeling [134].

\section{Diabetic cardiomyopathy-induced HF}

Animal models have been extensively used in diabetes research. Their utility can be questioned due to species differences; however, rodent models share many features with human diabetic cardiomyopathy. For example, rodent models of obesity, insulin resistance and type 2 diabetes present LV hypertrophy, diastolic dysfunction, increased cardiac fatty acid uptake and utilization, decreased cardiac 
efficiency, impaired mitochondrial energetics, increased myocardial lipid storage, and impaired $\mathrm{Ca}^{2+}$ handling [4, 19, 31].

There are a number of pharmacologic rodent models of diabetes: streptozotocin (STZ) administration to rats or mice, which induces diabetes mellitus (DM) as soon as $48 \mathrm{~h}$ post-injection [295]. This substance is selectively toxic to $\beta$-cells in the pancreatic islets, induces insulin deficiency and hyperglycemia and therefore represents a model of type 1 diabetes.

On the other hand, selective inbreeding has produced several strains of animal that are considered reasonable models of type 1 diabetes, type 2 diabetes and related phenotypes such as obesity and insulin resistance (Table 1). Apart from their use in studying the pathogenesis of the disease and its complications, all new treatments for diabetes, including islet cell transplantation and preventive strategies, are initially investigated in animals. In recent years, a large number of new genetic animal models for the study of diabetes, including knock-in, generalized and tissue-specific knockout mice, have been described. Rodent models of type 2 diabetes include the Zucker fatty rat, as well as $\mathrm{db} / \mathrm{db}$ and ob/ob mice, all of which display dysfunctional or absent leptin homeostasis and therefore develop insulin resistance in different timepoints.

In vivo studies in these rodents have revealed susceptibility to systolic and diastolic dysfunction using echocardiography and hemodynamic measurements [301]. They also exhibit a propensity to ischemia/reperfusion injury following LAD ligation, which occurs in conjunction with structural and functional changes to the LV [87]. However, there are several limitations when comparing these models to human diabetic cardiomyopathy, as spontaneous ischemia and atherosclerotic disease are not prominent in rodents [18]. The latter becomes simultaneously a valuable aspect as the effects of obesity, insulin resistance and diabetes on the heart can be studied independently of coronary artery disease [121]. Importantly, rodent models present fulminant and uncontrolled hyperglycemia or insulin resistance, while in the clinical setting patients with diabetes are increasingly well controlled as demonstrated by a recent study which found no evidence for diabetic cardiomyopathy in well-controlled patients with type 1 diabetes [141]. Moreover, because DM develops at varying stages in these models, it is important to keep in mind that studies performed in animals before the onset of diabetes may reflect changes that are secondary to the underlying obesity and insulin resistance, and studies performed after the onset of diabetes may reflect the added effects of hyperglycemia of different durations.

In conclusion, each model has certain limitations and no perfect model exists that exactly mimics human diabetic cardiomyopathy (Table 1).
Diastolic HF models

In spite of the rising prevalence of DHF, currently there is no evidence-based treatment strategies capable of changing its natural history, reflecting our poor understanding of this HF subtype [314]. Therefore, animal models of diastolic dysfunction and DHF urge for the development and preclinical evaluation of new effective therapies for this disease. However, animal models of DHF are rather scarce, thus leading to the utilization of diastolic dysfunction models, which are more widely published and very similar regarding the basic pathophysiologic mechanisms [60]. Furthermore, these models have been most commonly created in large animals, such as canine, sheep and swine. Nonetheless, there have been some successful rodent models that deserve to be highlighted in this review.

Animal models have tried to reproduce the paramount risk factors typically associated with diastolic dysfunction and DHF, namely aging, diabetes mellitus and hypertension [327]. In fact, the alterations in myocardial relaxation and stiffness associated with chronic hypertension and diabetes have been already mentioned above in the appropriate models, namely Dahl-salt-sensitive rats, DOCA-salt rats and diabetic cardiomyopathy.

Despite the great difficulty in developing an animal model of DHF age-induced, a recent study has characterized a model demonstrating isolated diastolic dysfunction associated with accelerated aging [235]. This mouse model is a spontaneous senescence model that displays many common geriatric disorders in the human population and recapitulates diastolic dysfunction as it naturally occurs in the elderly. Diastolic dysfunction, accompanied by fibrosis and an increase in pro-fibrotic cytokines, develops between 3 and 6 months of age, which is an early timepoint in the life span of these animals. This suggests that the physiologic abnormality manifests over a relatively short period of time and, from an experimental standpoint, adds an advantage as it allows for a more rapid study of pathophysiologic mechanisms. The senescence-accelerated mouse model will probably turn to be a useful model for future studies of age-related diastolic dysfunction, since the better insight into its underlying mechanisms could pave the way for designing specific pharmacologic strategies to prevent or treat this pathology [235].

The association between aging and diastolic dysfunction had already been addressed in a previous study, which compared adult (6-month-old) and old (24-month-old) Fischer 344/BNF1 rats after either 12 weeks of treadmill training or normal sedentary cage life [26]. Echocardiographic indices of $\mathrm{LV}$ relaxation were significantly lower in the old rats, but with training, they increased back to the levels seen in the adults. LV stiffness measured in isolated perfused hearts was not affected by age or training, but 


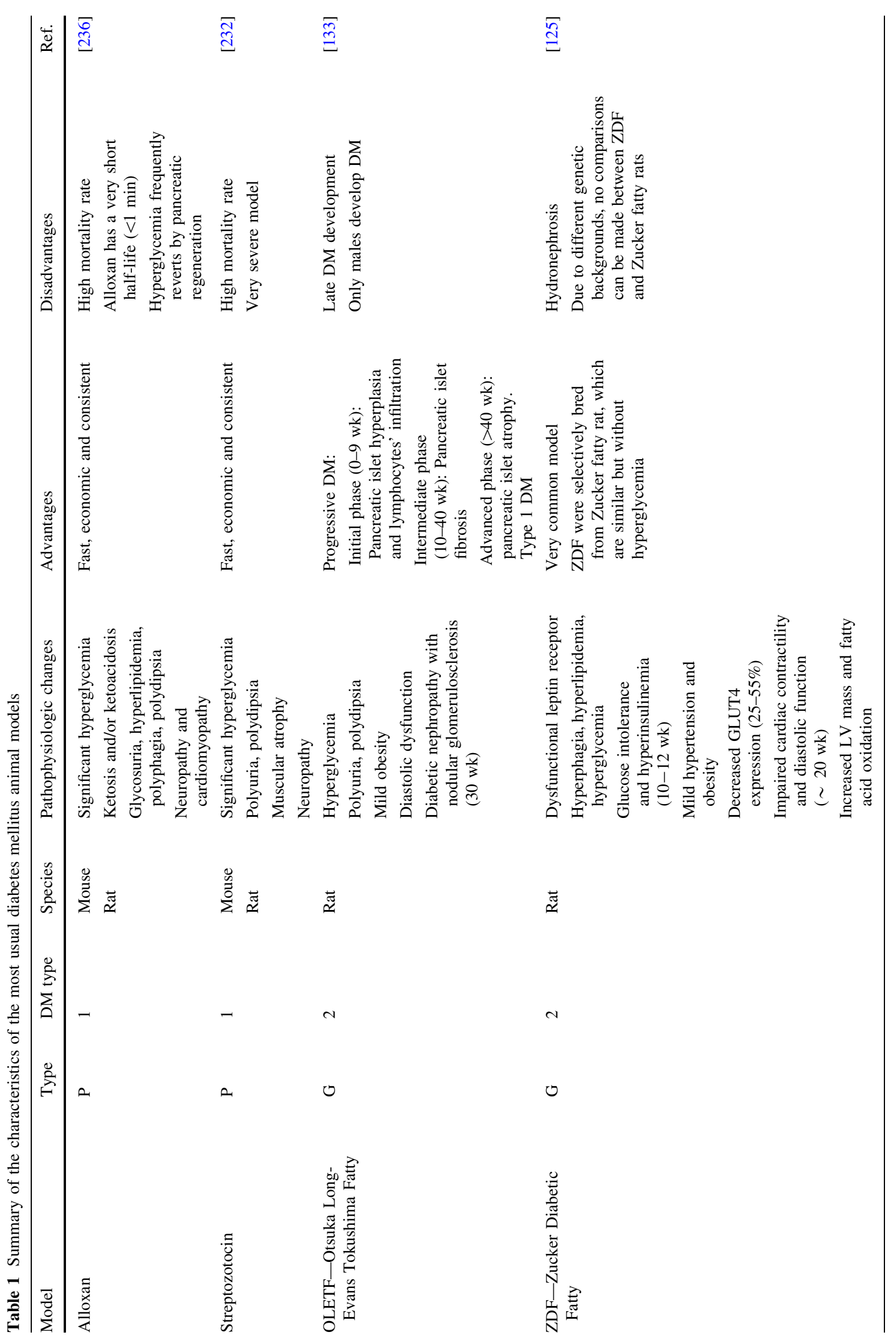




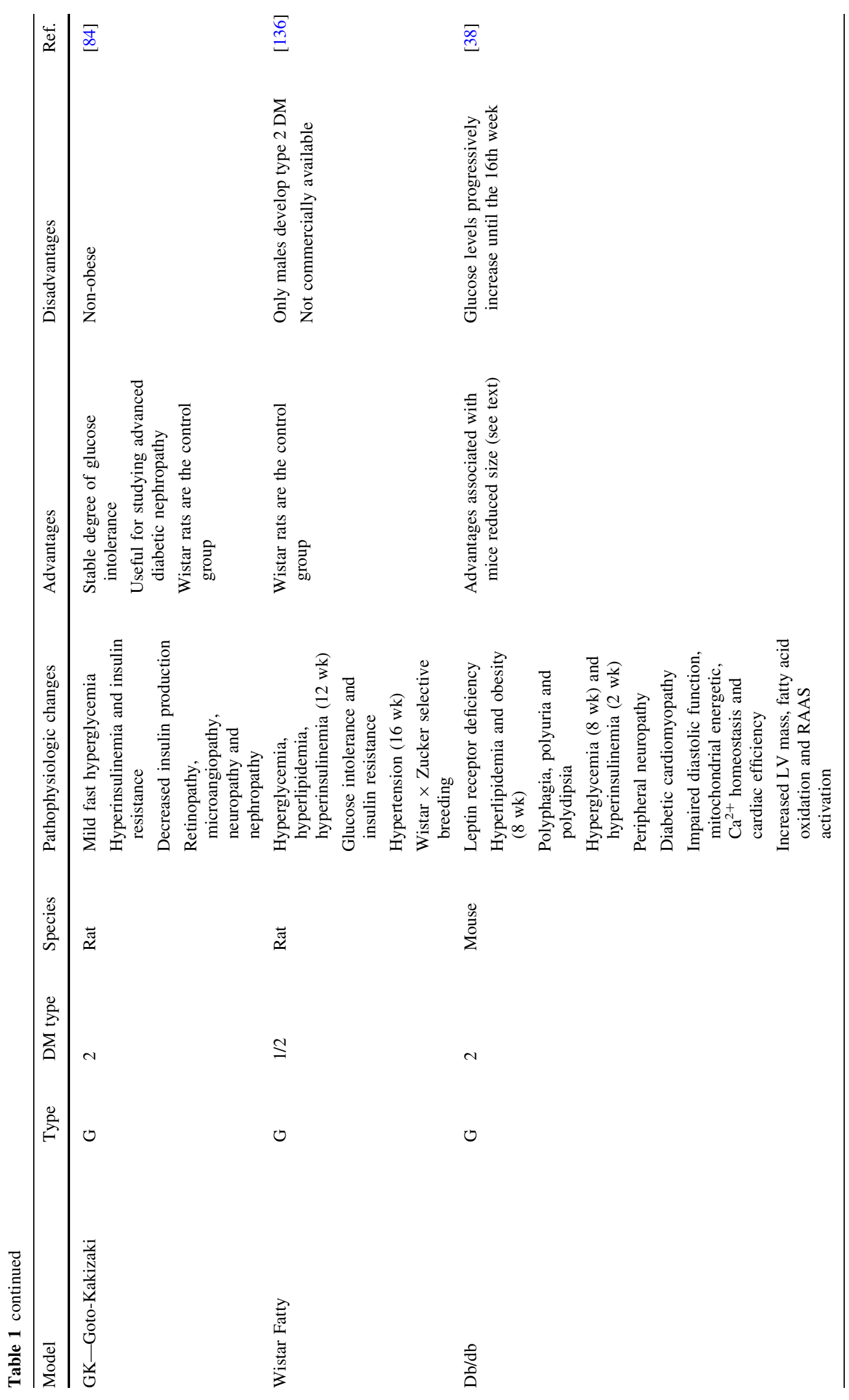




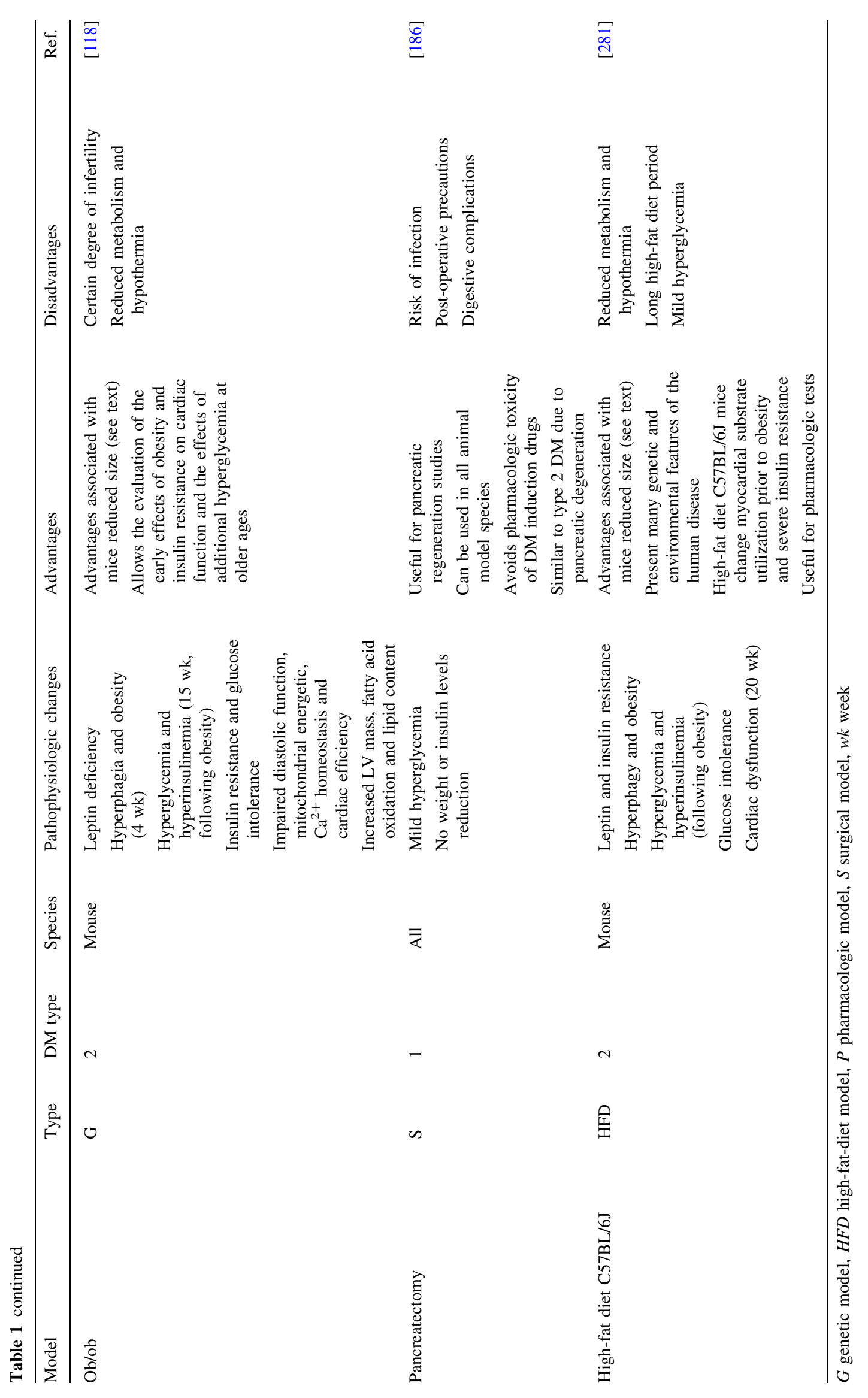


increased more rapidly during low-flow ischemia in the old hearts than in the adults. Again, training eliminated this age-associated difference in the response to ischemia, although it was not ascertained if the improvement was due to reversal of aging consequences or superimposition of some other effects. These findings indicate that in rats some age-associated changes in diastolic function are reversible and thus may not be intrinsic to aging but instead secondary to other processes, such as deconditioning [26].

\section{Syrian cardiomyopathic hamster}

The Syrian cardiomyopathic hamster is an established animal model for genetic cardiomyopathy, which has been extensively used since it was firstly described in 1962 by Homburger et al. [109]. They characterized an inbred line of Syrian hamster named BIO1.50 that experienced both cardiomyopathy and muscular dystrophy with $100 \%$ penetrance and [109] present an autosomal recessive mode of transmittance [109], thus being very useful for studying both cardiac and skeletal muscle disorders. Afterward, selective crossings gave rise to a new line, BIO14.6, which is now more widely used throughout the world [110]. Indeed, hitherto several cardiomyopathic hamsters (CM hamsters) have been derived from BIO14.6. Jasmin and colleagues established a new inbred line of UMX7.1 by cross-breeding BIO14.6 with unrelated healthy hamsters [126]. Later, another substrain of these hamster was isolated, the J2N [210]. The descendants of BIO14.6 and UMX7.1 were named as CHF146 and CHF147, respectively, and have been maintained at Canadian Hybrid Farms in Nova Scotia, Canada [113]. All the five CM hamsters (BIO14.6, UMX7.1, J2N, CHF146 and CHF147) develop an identical cardiomyopathy, progressing through prenecrotic, necrotic, hypertrophic and dilated stages [108]. Therefore, the disease progression in the hamster parallels the human genetic disease [66].

The most remarkable genetic manipulation of $\mathrm{CM}$ hamsters is the isolation of BIO53.58 from BIO14.6 [108]. Contrary to their forebears, BIO53.58 has a shorter lifeexpectancy and achieves much faster the disease endpoint of marked chamber dilation, which is common to all the CM hamsters, apparently without developing previous cardiac hypertrophy. Several descendants of BIO53.58, such as TO, TO-2 and MS200, were developed [180], and TO-2 is now maintained at Bio-Research Institute.

All the CM hamsters share the genomic deletion of about $30-\mathrm{kb}$ interval, which includes the two promoters and first exons of delta-sarcoglycan gene with consequent loss of its protein product $[212,248,249]$. The consequences of the genetic loss of delta-sarcoglycan in heart are related not only to sarcolemmal fragility but also to coronary vasospasm from disruption of dystrophin-associated protein complex [44]. A genetic insult yet to be discovered was probably introduced during the isolation of BIO53.58 and has been inherited by its descendants, which could explain its distinct cardiomyopathy.

Pathophysiologically, two basic mechanisms contribute to cardiomyopathy in this model: (1) ischemic heart disease by vasospasm of the coronary circulation and (2) cardiomyocyte loss due to intrinsic cell defects [66]. Reports suggested that the vascular RAAS plays a critical role in the generation of increased coronary reactivity and resistance in young Syrian CM hamsters that have not yet developed the clinical manifestations of HF, being the increased reactivity due to endothelial dysfunction secondary to angiotensin-II-dependent oxidative stress [66]. Indeed, blockade of the RAAS during early stages of disease improves the clinical manifestations of dilated cardiomyopathy in this model [66]. With regard to cardiomyocyte loss, numerous studies showed autophagic vacuolar degeneration in cardiomyocytes, which could be improved by treatment with granulocyte colony-stimulating factor [288]. Another report provided novel evidence of a beneficial effect of vascular endothelial growth factor in the Syrian CM hamster via induction of myogenic growth factor production by skeletal muscle and mobilization of progenitor cells, which resulted in attenuation of cardiomyopathy and repair of the heart [328].

Moreover, the Syrian CM hamster has been shown to develop alterations in electrical and ionic homeostasis related to disruption of gap junctions, which contributes to arrhythmogenesis during the development of HF [247]. A recent report showed that adhesion junction precedes gap junction alterations and that angiotensin-II receptor blockade might be a new therapy for lethal ventricular arrhythmia by modulating both adhesion junctions and gap junctions remodeling [323].

In summary, several reports confirm that $\mathrm{CM}$ hamsters with genetic loss of delta-sarcoglycan recapitulate many pathophysiologic aspects of cardiac failure [39, 267, 296], but it is clear that despite its extended use, this model is far from being totally understood [247].

\section{Genetically engineered rodent models}

The development of molecular biology offers the opportunity to study the impact of overexpression or deletion of specific genes involved in the pathophysiology of CHF. Indeed, transgenic murine models will help understanding the molecular basis of CHF, which might open the door for the development of novel molecular targets for the treatment of CHF. A wide number of genetic modifications have been successfully introduced in mice, either in terms 
of gain or loss of function. Besides the genetically engineered mouse models summarized in Table 2, other selective inbreed and other genetic animal models were presented in previous sections whenever appropriate.

\section{General considerations}

Besides ethical and philosophical questions, the use of animal models of HF needs careful consideration not only because the disease may be associated with discomfort and pain to the animal but also because results from animal studies are not readily transferable to human patients.

HF models were originally developed in rodents because of numerous potential advantages inherent to a small animal model. Housing and maintenance costs for rodents are much lower than for larger animals, thus allowing increasing the number of animals included in a given study and improving its statistical power. Moreover, recent technological advances in echocardiography, MRI and micromanometer conductance catheters have greatly upgraded the assessment of cardiac function in rodents, removing a significant barrier to their use in HF research.

The small size of mice presents some challenges in assessing myocardial function by conventional techniques (echocardiography, MRI), and the tenfold bigger myocardial mass of rats compared to mice gives the opportunity of performing more post-mortem histologic and biological analyses [223]. Nevertheless, cardiac physiologic assessments have been made easier by recent technologies such as ultrahigh resolution ultrasound [169] and micromanometer conductance for pressure-volume analyses [80, 218], but these techniques are quite expensive and pose a serious challenge to laboratories without an established expertise. The major advantage of mice compared to rats is the fact that pharmacologic studies become less expensive as the drug is usually administered proportionately to the animal weight. Moreover, mice are one of the most interesting research models to study the molecular basis of HF due to the availability of many genetically engineered strains made possible by their well-characterized genome and the easy introduction and stable transmission of gene mutations. Moreover, since $99 \%$ of the human genes have direct orthologs with mice, it is possible to generate transgenic mice models to mimic human disorders [71, 244]. Nevertheless, structural differences regarding human cardiovascular system represent another limitation of rodent models.

With regard to diastolic dysfunction, it should be emphasized that rodent models generally progress to SHF within a variable amount of time, which means in those animals DHF is only temporary step in the development of SHF. On the contrary, there are several human pathologies characterized by stable and isolated DHF, thus not evolving to systolic dysfunction. Therefore, small animal models could be misleading because they suggest that DHF invariably progress to SHF, which in fact seldom happens in humans. Additionally, in humans, DHF is a condition typically associated with aging, and the diastolic dysfunction/DHF animal models herein mentioned are relatively young.

Care should be taken when dealing with genetically engineered mice. Besides taking into account strain and gender issues [91, 272, 283], high levels of overexpression must be carefully interpreted. In fact, transgenic mice that express a biologically inert green fluorescent protein in a cardiomyocyte-specific fashion develop LV hypertrophy, dilation and systolic dysfunction in a manner directly related to the level of protein expression. Therefore, nonspecific effects on LV structure and function may result from vast overexpression of even biologically inactive proteins [112]. Furthermore, certain phenotypes depend on the expression level of the gene concerned [43, 298], which means it is necessary to develop multiple transgenic lines to establish a gene-dosage effect. Development of compensatory mechanisms could be triggered in response to gene overexpression or deletion at a very early stage after manipulation, masking the direct effects of the targeted gene. The use of inducible and conditional gene activation or deactivation could be a good way of overcoming this problem [306]. In conclusion, despite the inherent pitfalls in transgenesis, many of them can be circumvented by creating additional transgenic lines that can be used as controls to check dosage or epigenetic sequelae, as has been recently reviewed [202]. A number of difficulties in interpreting a cardiac transgenic experiment can arise from the promoter that drives the transgene itself. For example, although the $\alpha$-myosin heavy chain $(\alpha-\mathrm{MHC})$ promoter is often thought of as driving ventricular expression in the adult, its actual expression pattern is considerably more nuanced, with transient expression in the embryonic heart tube and atrial expression throughout development. If the experimenter is attempting to isolate events that occur as a result of expression only in the adult, more precise manipulation of transgene expression may be necessary to generate interpretable data. Inducible transgene expression allows precise and reversible expression of a normal or mutated protein that can be directed to a particular cell type at a particular developmental time. A number of druginducible systems have been described, but the tetracycline-based system is the most effective and widely used. However, like most tools, it must be used carefully as the tetracycline activator can, when expressed at high levels or for long periods of time, be cardiotoxic. Despite this concern, transactivator lines have been developed that show no cardiotoxicity for at least 6 months, and so these experimental limitations can be easily circumvented [250]. 


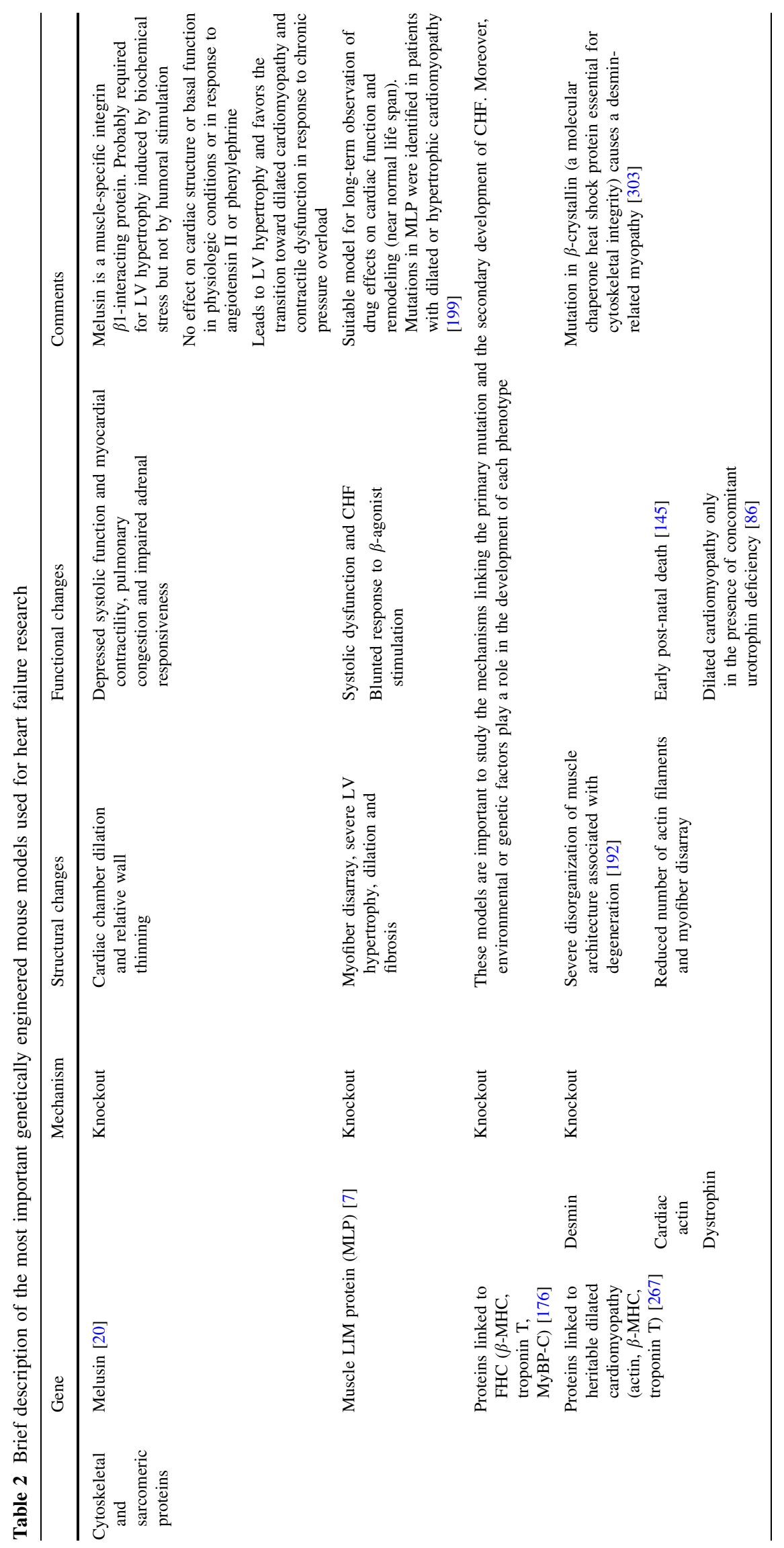




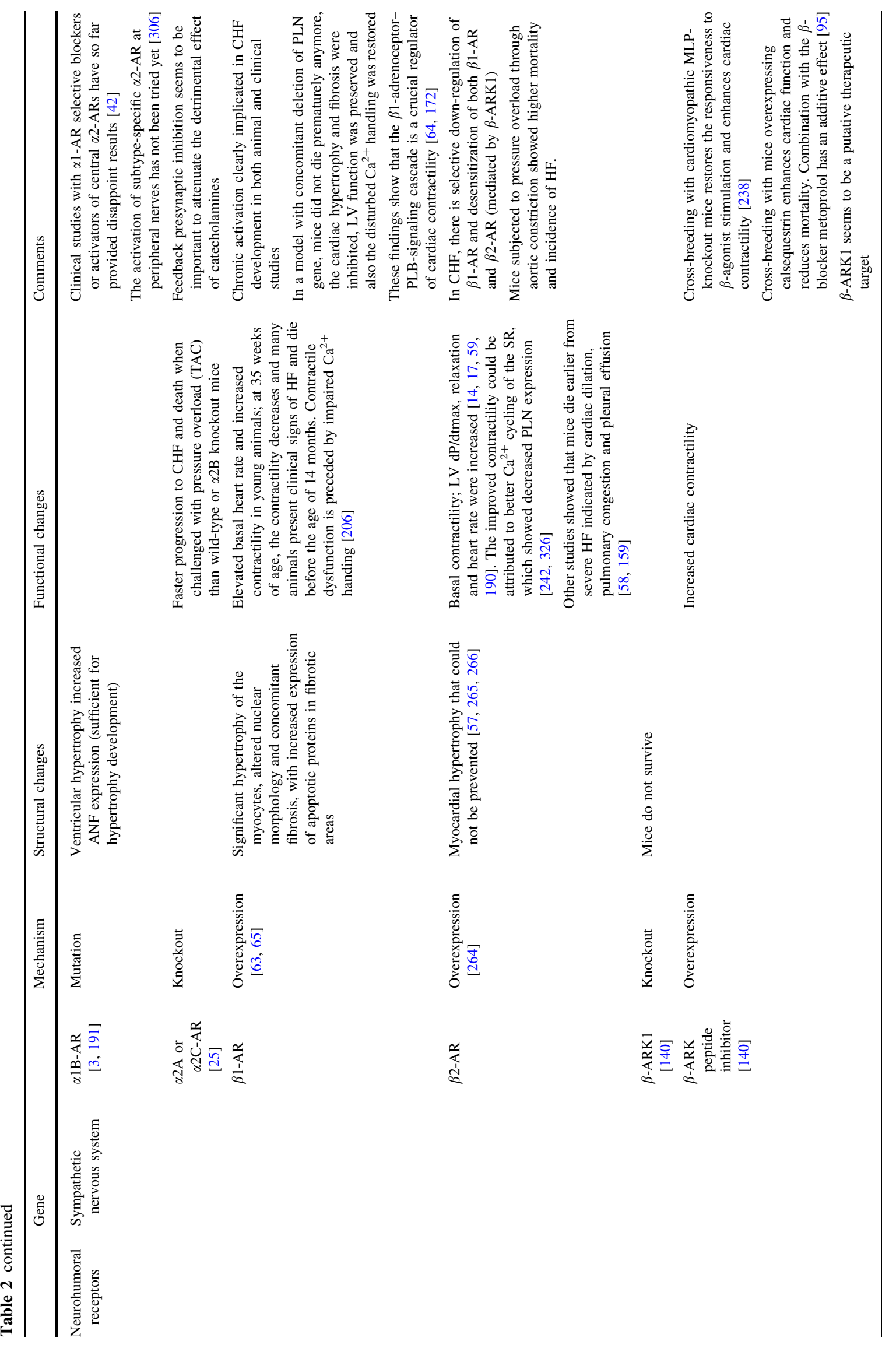




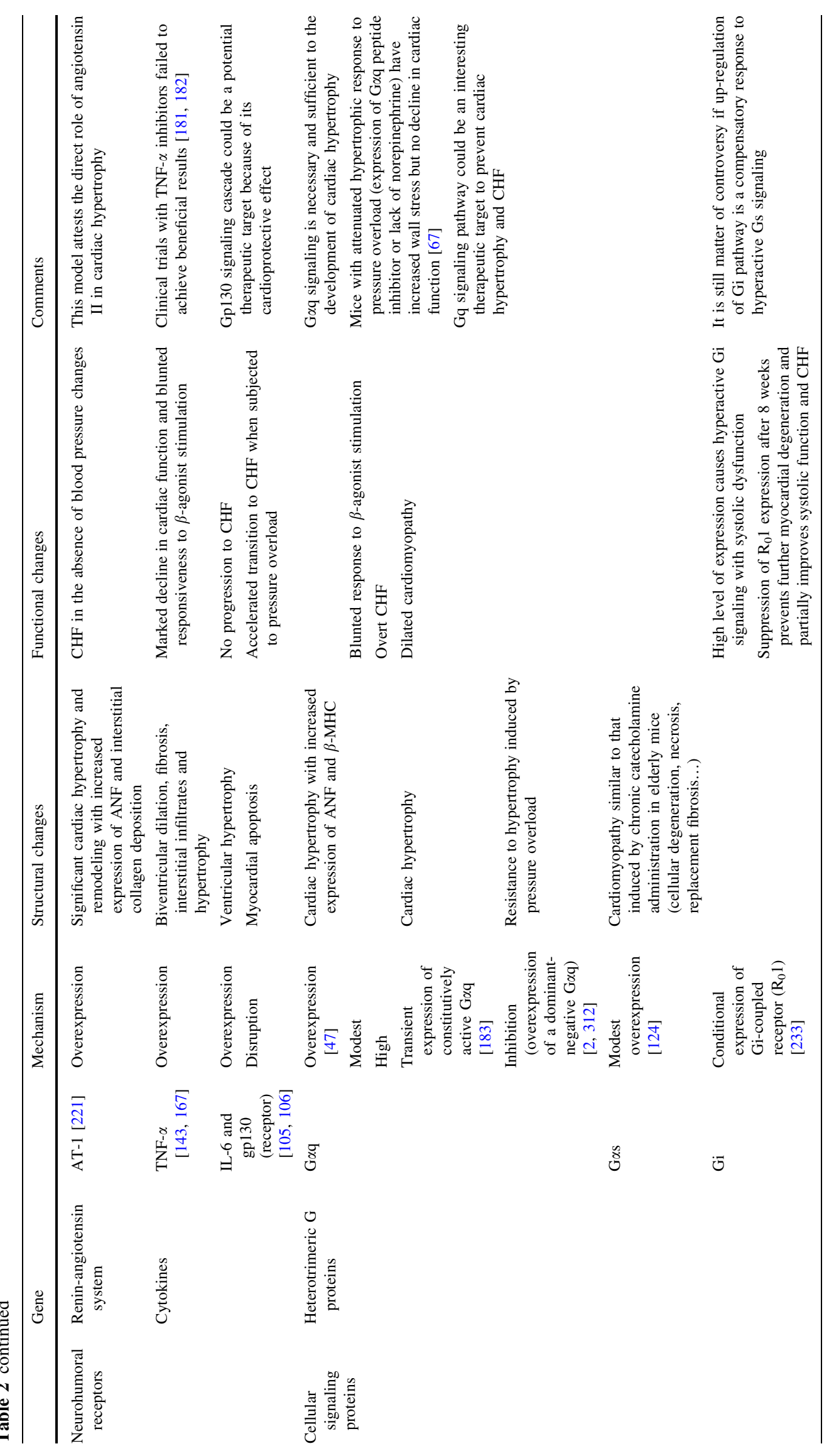



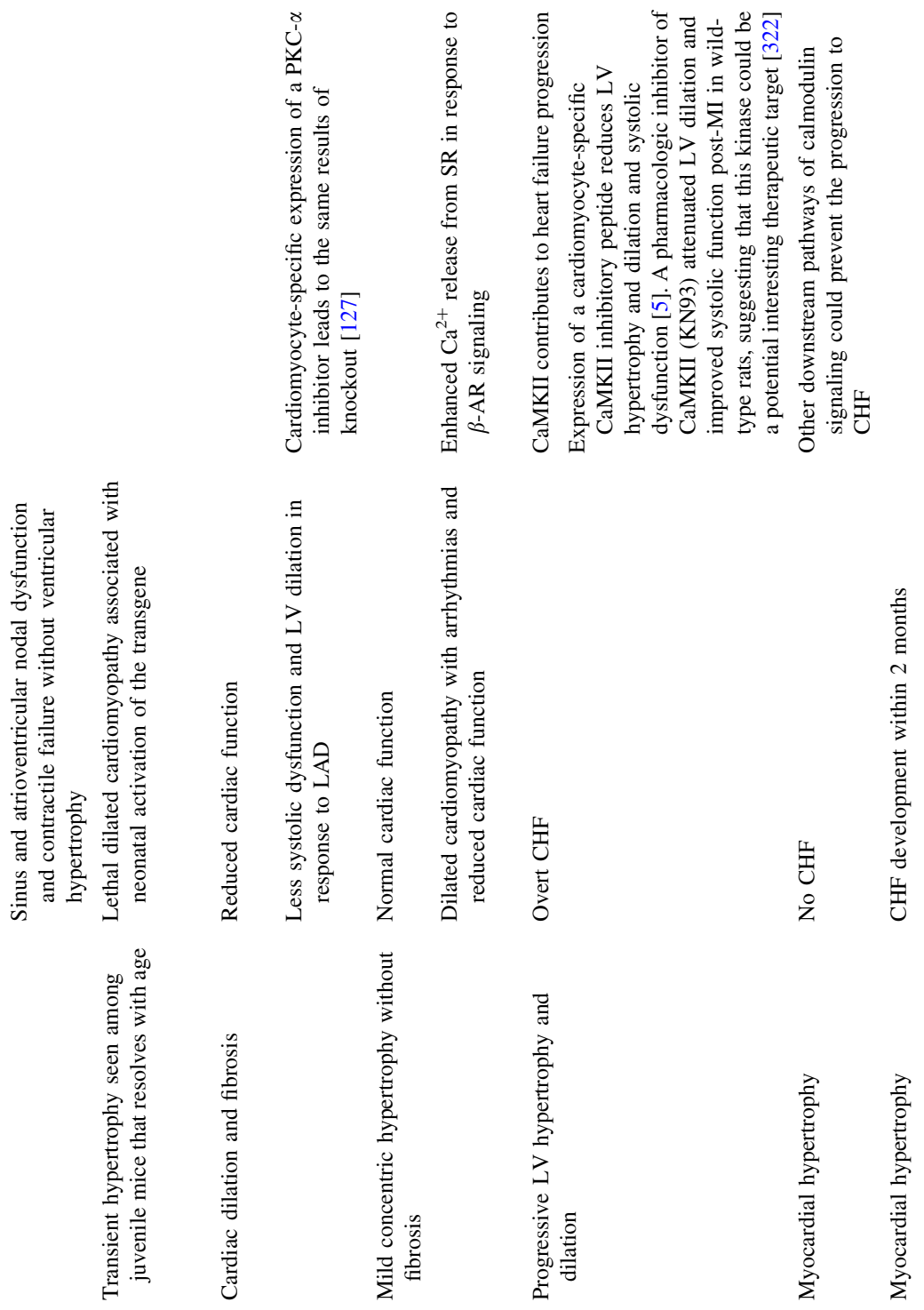

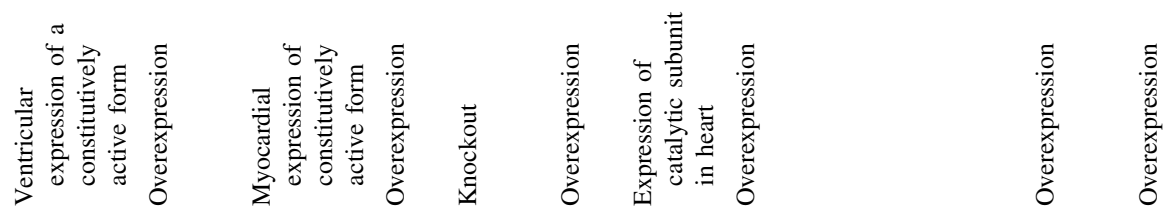

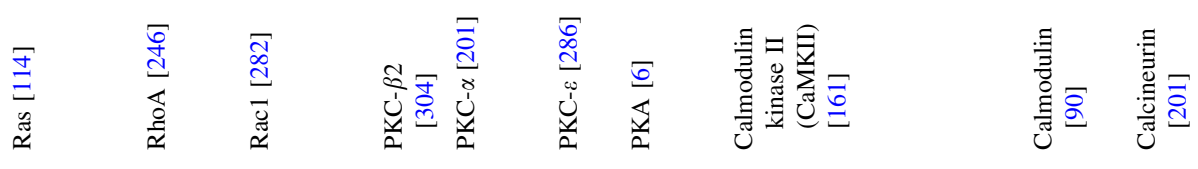

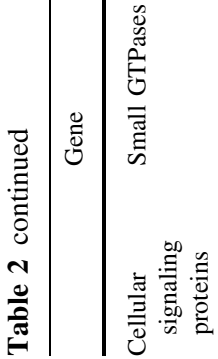

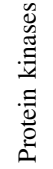




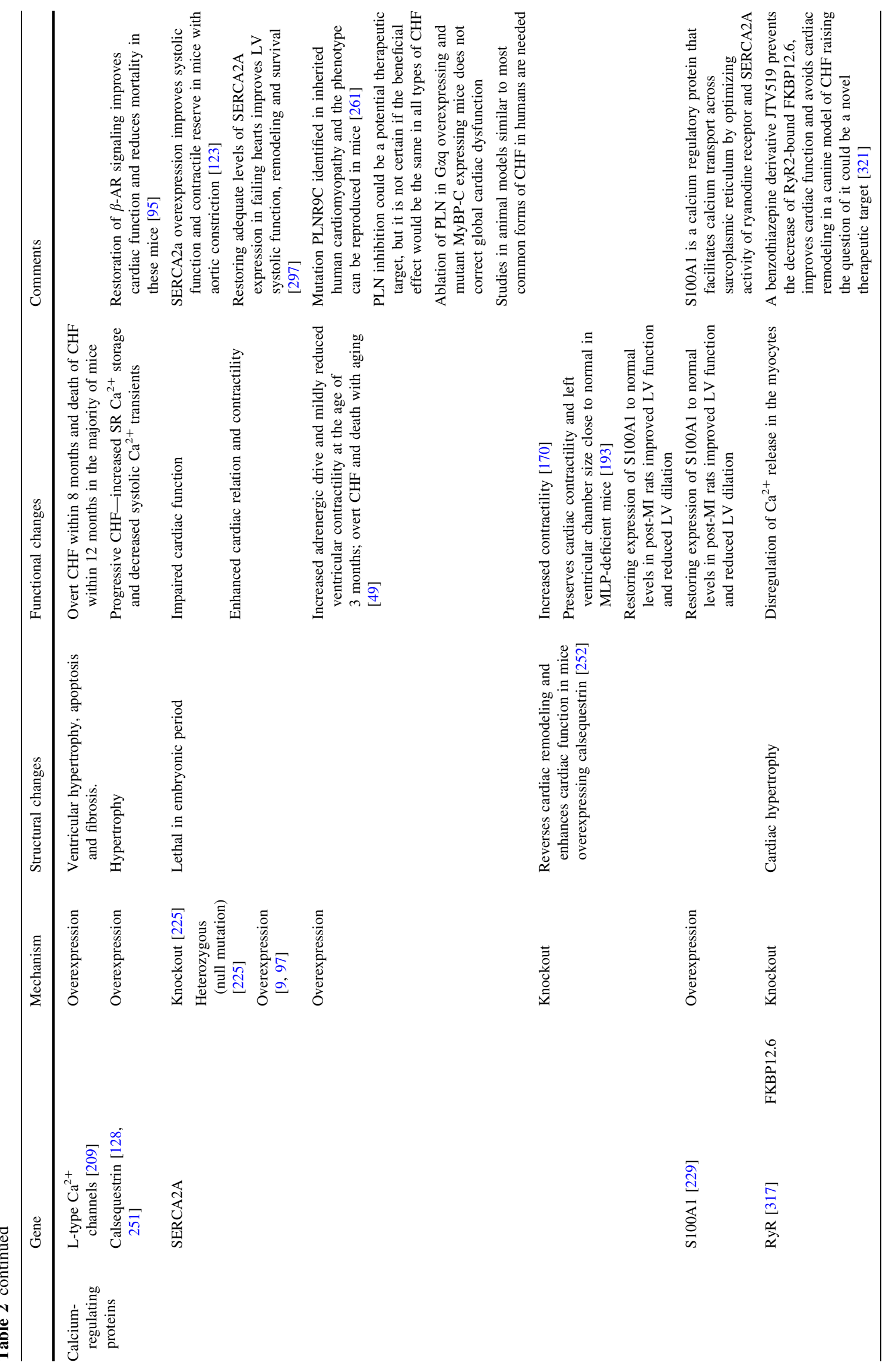




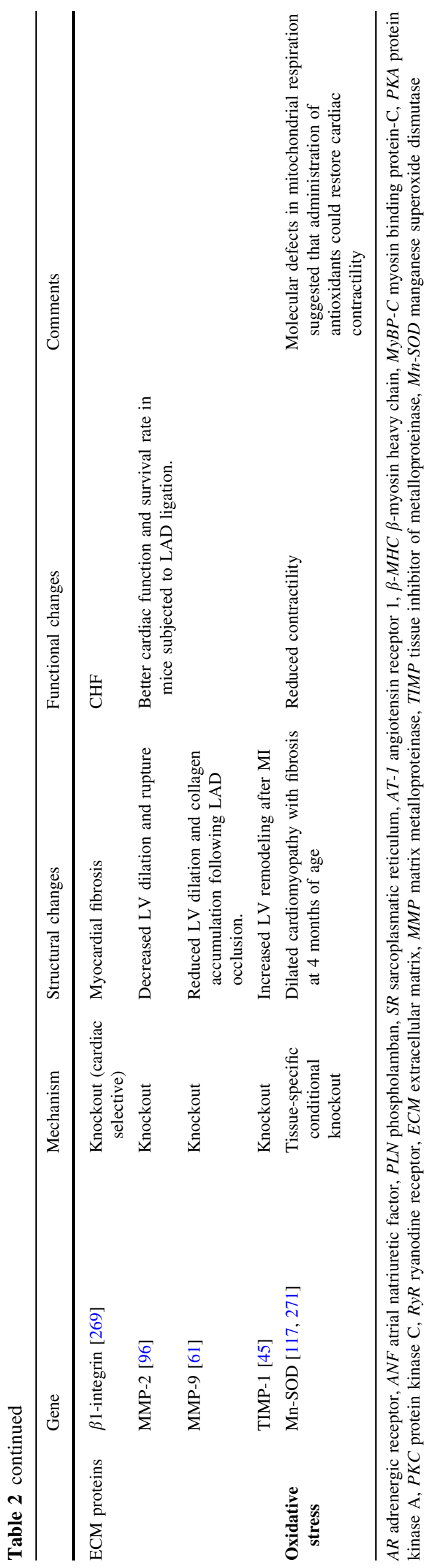

Gene targeting has often been heralded as being more precise and useful than transgenesis. When coupled with tissue- or cell type-specific methodologies via Cre-lox technology, gene targeting offers a precise way of introducing specific mutations that will only be expressed in a defined cell type at a particular developmental time. Nonetheless, the continuous expression of the Cre recombinase system has been shown to cause decreased growth, cytopathic effects and chromosomal aberrations in cultured cells lacking exogenous lox sites [260, 275]. A selfexcising retroviral vector that incorporates a negative feedback loop to limit the duration and intensity of Cre expression can avoid measurable toxicity, while retaining the ability to excise a target sequence flanked by lox sites, thus providing the basis of a less toxic strategy for the use of Cre or similar recombinases [275]. As is the case for transgenesis, the more precisely the targeting event can be manipulated, the more straightforward the data interpretation will be. In the heart, this is accomplished by rendering the targeting event cardiomyocyte specific via controlled Cre expression using a cardiomyocyte-specific promoter or even making cardiomyocyte-specific Cre expression inducible [277]. However, several reports have noted some cardiac toxicity due to high levels of Cre expression with the $\alpha$-MHC promoter, especially in later adulthood [202]. One putative solution is to design the experiment such that the data are obtained before cardiac function and biochemistry are affected, circumventing any negative effect of Cre expression. More importantly, employing Cre-only transgenic mice in the same genetic background as part of the overall experimental design is absolutely necessary for proper data interpretation and to ascertain any potential effect of Cre alone. Alternatively, different cardiac Cre transgenes may be used. Moreover, tamoxifen administration only in the presence of the $\alpha$-MHC-MerCreMer transgene produces a temporary reduction in cardiac function with some ventricular dilation, although this phenotype resolves in 7-14 days after tamoxifen administration [202]. Thus, if the MerCreMer transgene is used to inducibly delete a gene from the heart, controls that only contain this transgene with tamoxifen are critical.

Another drawback of rodent models is that many protocols have a sudden onset of HF due to a surgical or drug intervention, whereas human HF generally develops over a period of several years. Most models also use young adult animals, while human patients are usually old. In addition, human HF is often associated with atherosclerosis, hypertension, diabetes or obesity, but the development of atherosclerosis is rather rare in most rodent strains [92].

In addition, even though rodent models have been extremely useful in developing concepts concerning the pathogenesis of heart failure, apart from the Pfeffer's model [228], which predicted the utility of ACE inhibitors 
in post-infarction [227], they have not predicted outcomes in phase III clinical trials. Although translation of findings to clinical trials requires preclinical studies where the appropriate animal model is used for either acute or chronic $\mathrm{HF}$, therapeutic results obtained in small animal models are not necessarily predictive of outcomes in human patients but can provide a potential future approach in the human context. In this regard, two recent examples could be mentioned. Inhibitors of enzymes in the PDE5 family have been used to raise cGMP content in cardiac muscle in animal models of pressure overload, chronic $\beta$-adrenergic receptor stimulation, ischemic injury and doxorubicin toxicity showing antihypertrophic and cardioprotective actions. However, recent experimental results raise some question regarding the applicability of these findings to humans, in whose hearts PDE5 is present at much lower levels than those seen in animal models, and raise the possibility of PDE1, a dual-specificity phosphodiesterase present at high levels in human myocardium, as an alternative target for inotropic and cardioprotective actions [205]. On the other hand, despite the evidence for inflammatory activation as an important pathway in disease progression in chronic HF and the promising results of 'anti-inflammatory' therapies (such as antitumor necrosis factor- $\alpha$ approaches) in rodent models [146], clinical trials have hitherto failed to show benefit in HF patients [101]. The discrepancy between clinical and basic research findings could be explained by the inherent physiologic differences between humans and rodents in terms of pharmacokinetics and pharmacogenetics. On the other hand, several authors reinforce the importance of refining patient selection in order to optimize the benefits of new HF drugs [101, 174].

Finally, the majority of the numerous genetic studies performed in mice have not resulted in clinically approved treatment in humans thus far [202]. However, it is not uncommon for a drug to take over 20 years from inception to clinical application. Given that genetically modified mouse models have only recently become a mainstay approach, it may take many more years before approaches based on this technology are introduced into clinical practice.

\section{Conclusion}

The use of small animal models has proven to be an extremely valuable tool in understanding the pathophysiology of complex cardiovascular diseases like CHF. Due to the recent development of invasive and non-invasive techniques to evaluate hemodynamics in human patients, animal models of HF are becoming less important to study hemodynamics, neurohumoral activation and myocardial function. Furthermore, with cardiac transplantation surgery, end-stage human myocardium become available for molecular and biochemical studies. Nevertheless, animal models remain critically important to study myocardial changes during compensated, initial stages of $\mathrm{CHF}$, during transition from hypertrophy to failure and during the process of remodeling, all of which are currently difficult or even impossible to follow serially in human patients. Animal models may also be relevant to study the effects of new pharmacologic interventions on hemodynamics, neurohumoral activation and survival under preclinical conditions.

At present, transgenic models of CHF are essential for understanding the molecular alterations underlying the development of the disease, as they allow the identification of genes that are causative for $\mathrm{HF}$ and to characterize molecular mechanisms responsible for the development and progression of the disease.

Finally, animal models that mimic distinct features of human HF will play an important role in unraveling the consequences of gene transfer and molecular techniques to correct disturbed subcellular processes in the failing heart. These experiments are indispensable, and these rodent models will continue to held an important role, not only in expanding our knowledge about the mechanisms underlying HF, but also in developing novel therapeutic strategies for CHF.

Acknowledgments This work was supported by a grant from the European Commission (FP7-Health-2010; MEDIA-261409). Inês Falcão-Pires, Ana Luisa Pires and Carmen Brás-Silva are supported by an individual grants from Portuguese Foundation for Science and Technology (SFRH/BPD/66176/2009, SFRH/BD/19544/2004 as well as Ciência 2008 and PTDC/SAU-FCT/100442/2008, COMPETE, FEDER, respectively).

\section{References}

1. Abbate A, Scarpa S, Santini D, Palleiro J, Vasaturo F, Miller J, Morales C, Vetrovec GW, Baldi A (2006) Myocardial expression of survivin, an apoptosis inhibitor, in aging and heart failure. An experimental study in the spontaneously hypertensive rat. Int J Cardiol 111:371-376. doi:10.1016/j.ijcard.2005. 07.061

2. Akhter SA, Luttrell LM, Rockman HA, Iaccarino G, Lefkowitz RJ, Koch WJ (1998) Targeting the receptor-Gq interface to inhibit in vivo pressure overload myocardial hypertrophy. Science 280:574-577

3. Akhter SA, Milano CA, Shotwell KF, Cho MC, Rockman HA, Lefkowitz RJ, Koch WJ (1997) Transgenic mice with cardiac overexpression of alpha1B-adrenergic receptors. In vivo alpha1adrenergic receptor-mediated regulation of beta-adrenergic signaling. J Biol Chem 272:21253-21259

4. An D, Rodrigues B (2006) Role of changes in cardiac metabolism in development of diabetic cardiomyopathy. Am J Physiol Heart Circ Physiol 291:H1489-1506. doi:10.1152/ajpheart.002 78.2006 
5. Anderson ME (2005) Calmodulin kinase signaling in heart: an intriguing candidate target for therapy of myocardial dysfunction and arrhythmias. Pharmacol Ther 106:39-55. doi:10.1016/j. pharmthera.2004.11.002

6. Antos CL, Frey N, Marx SO, Reiken S, Gaburjakova M, Richardson JA, Marks AR, Olson EN (2001) Dilated cardiomyopathy and sudden death resulting from constitutive activation of protein kinase a. Circ Res 89:997-1004

7. Arber S, Hunter JJ, Ross J Jr, Hongo M, Sansig G, Borg J, Perriard JC, Chien KR, Caroni P (1997) MLP-deficient mice exhibit a disruption of cardiac cytoarchitectural organization, dilated cardiomyopathy, and heart failure. Cell 88:393-403

8. Arnolda L, McGrath B, Cocks M, Sumithran E, Johnston C (1985) Adriamycin cardiomyopathy in the rabbit: an animal model of low output cardiac failure with activation of vasoconstrictor mechanisms. Cardiovasc Res 19:378-382

9. Baker DL, Hashimoto K, Grupp IL, Ji Y, Reed T, Loukianov E, Grupp G, Bhagwhat A, Hoit B, Walsh R, Marban E, Periasamy M (1998) Targeted overexpression of the sarcoplasmic reticulum $\mathrm{Ca}_{2}{ }^{+}$-ATPase increases cardiac contractility in transgenic mouse hearts. Circ Res 83:1205-1214

10. Bayat H, Swaney JS, Ander AN, Dalton N, Kennedy BP, Hammond HK, Roth DM (2002) Progressive heart failure after myocardial infarction in mice. Basic Res Cardiol 97:206-213

11. Berg RG, Leenen FH, de Jong W (1979) Plasma renin activity and sodium, potassium and water excretion during reversal of hypertension in the one-clip two-kidney hypertensive rat. Clin Sci (Lond) 57:47-52

12. Bialik GM, Abassi ZA, Hammel I, Winaver J, Lewinson D (2001) Evaluation of atrial natriuretic peptide and brain natriuretic peptide in atrial granules of rats with experimental congestive heart failure. J Histochem Cytochem 49:1293-1300

13. Bing OH, Brooks WW, Robinson KG, Slawsky MT, Hayes JA, Litwin SE, Sen S, Conrad CH (1995) The spontaneously hypertensive rat as a model of the transition from compensated left ventricular hypertrophy to failure. J Mol Cell Cardiol 27: 383-396

14. Bittner HB, Chen EP, Milano CA, Lefkowitz RJ, Van Trigt P (1997) Functional analysis of myocardial performance in murine hearts overexpressing the human beta 2 -adrenergic receptor. J Mol Cell Cardiol 29:961-967. doi:10.1006/jmcc.1996.0339

15. Boluyt MO, O'Neill L, Meredith AL, Bing OH, Brooks WW, Conrad CH, Crow MT, Lakatta EG (1994) Alterations in cardiac gene expression during the transition from stable hypertrophy to heart failure. Marked upregulation of genes encoding extracellular matrix components. Circ Res 75:23-32

16. Boluyt MO, Robinson KG, Meredith AL, Sen S, Lakatta EG, Crow MT, Brooks WW, Conrad CH, Bing OH (2005) Heart failure after long-term supravalvular aortic constriction in rats. Am J Hypertens 18:202-212. doi:10.1016/j.amjhyper.2004. 08.034

17. Bond RA, Leff P, Johnson TD, Milano CA, Rockman HA, McMinn TR, Apparsundaram S, Hyek MF, Kenakin TP, Allen LF et al (1995) Physiological effects of inverse agonists in transgenic mice with myocardial overexpression of the beta 2-adrenoceptor. Nature 374:272-276. doi:10.1038/374272a0

18. Boudina S, Abel ED (2007) Diabetic cardiomyopathy revisited. Circulation 115:3213-3223. doi:10.1161/CIRCULATIONAHA. 106.679597

19. Boudina S, Sena S, Theobald H, Sheng X, Wright JJ, Hu XX, Aziz S, Johnson JI, Bugger H, Zaha VG, Abel ED (2007) Mitochondrial energetics in the heart in obesity-related diabetes: direct evidence for increased uncoupled respiration and activation of uncoupling proteins. Diabetes 56:2457-2466. doi: $10.2337 / \mathrm{db} 07-0481$
20. Brancaccio M, Fratta L, Notte A, Hirsch E, Poulet R, Guazzone S, De Acetis M, Vecchione C, Marino G, Altruda F, Silengo L, Tarone G, Lembo G (2003) Melusin, a muscle-specific integrin beta1-interacting protein, is required to prevent cardiac failure in response to chronic pressure overload. Nat Med 9:68-75. doi: $10.1038 / \mathrm{nm} 805 \mathrm{~nm} 805$

21. Bras-Silva C, Fontes-Sousa AP, Moura C, Areias JC, LeiteMoreira AF (2006) Impaired response to ET(B) receptor stimulation in heart failure: functional evidence of endocardial endothelial dysfunction? Exp Biol Med (Maywood) 231:893898

22. Bras-Silva C, Leite-Moreira AF (2008) Myocardial effects of endothelin-1. Rev Port Cardiol 27:925-951

23. Braun A, Trigatti BL, Post MJ, Sato K, Simons M, Edelberg JM, Rosenberg RD, Schrenzel M, Krieger M (2002) Loss of SR-BI expression leads to the early onset of occlusive atherosclerotic coronary artery disease, spontaneous myocardial infarctions, severe cardiac dysfunction, and premature death in apolipoprotein E-deficient mice. Circ Res 90:270-276

24. Braunschweig F, Cowie MR, Auricchio A (2011) What are the costs of heart failure? Europace 13(Suppl 2):ii13-17. doi: 10.1093/europace/eur081

25. Brede M, Wiesmann F, Jahns R, Hadamek K, Arnolt C, Neubauer S, Lohse MJ, Hein L (2002) Feedback inhibition of catecholamine release by two different alpha2-adrenoceptor subtypes prevents progression of heart failure. Circulation 106:2491-2496

26. Brenner DA, Apstein CS, Saupe KW (2001) Exercise training attenuates age-associated diastolic dysfunction in rats. Circulation 104:221-226

27. Bristow MR, Thompson PD, Martin RP, Mason JW, Billingham ME, Harrison DC (1978) Early anthracycline cardiotoxicity. Am J Med 65:823-832

28. Brower GL, Levick SP, Janicki JS (2007) Inhibition of matrix metalloproteinase activity by ACE inhibitors prevents left ventricular remodeling in a rat model of heart failure. Am J Physiol Heart Circ Physiol 292:H3057-3064. doi:10.1152/ajpheart.004 47.2006

29. Brown L, Ooi SY, Lau K, Sernia C (2000) Cardiac and vascular responses in deoxycorticosterone acetate-salt hypertensive rats. Clin Exp Pharmacol Physiol 27:263-269

30. Buermans HP, Redout EM, Schiel AE, Musters RJ, Zuidwijk M, Eijk PP, van Hardeveld C, Kasanmoentalib S, Visser FC, Ylstra B, Simonides WS (2005) Microarray analysis reveals pivotal divergent mRNA expression profiles early in the development of either compensated ventricular hypertrophy or heart failure. Physiol Genomics 21:314-323. doi:10.1152/physiolgenomics. 00185.2004

31. Bugger H, Abel ED (2008) Molecular mechanisms for myocardial mitochondrial dysfunction in the metabolic syndrome. Clin Sci (Lond) 114:195-210. doi:10.1042/CS20070166

32. Burke SL, Evans RG, Head GA (2011) Effects of chronic sympatho-inhibition on renal excretory function in renovascular hypertension. J Hypertens 29:945-952. doi:10.1097/HJH.0b0 $13 \mathrm{e} 3283449529$

33. Calderone A, de Champlain J, Rouleau JL (1991) Adriamycininduced changes to the myocardial beta-adrenergic system in the rabbit. J Mol Cell Cardiol 23:333-342

34. Cantor EJ, Babick AP, Vasanji Z, Dhalla NS, Netticadan T (2005) A comparative serial echocardiographic analysis of cardiac structure and function in rats subjected to pressure or volume overload. J Mol Cell Cardiol 38:777-786. doi:10.1016/ j.yjmcc.2005.02.012

35. Carvalho KA, Guarita-Souza LC, Hansen P, Rebelatto CL, Senegaglia AC, Miyague N, Olandoski M, Francisco JC, 
Furuta M, Gremski W (2006) Cell transplantation after the coculture of skeletal myoblasts and mesenchymal stem cells in the regeneration of the myocardium scar: an experimental study in rats. Transplant Proc 38:1596-1602. doi:10.1016/j.transpro ceed.2006.03.023

36. Cavallero S, Gonzalez GE, Puyo AM, Roson MI, Perez S, Morales C, Hertig CM, Gelpi RJ, Fernandez BE (2007) Atrial natriuretic peptide behaviour and myocyte hypertrophic profile in combined pressure and volume-induced cardiac hypertrophy. J Hypertens 25:1940-1950. doi:10.1097/HJH.0b013e3282435b 1e00004872-200709000-00026

37. Chekanov VS (1999) A stable model of chronic bilateral ventricular insufficiency (dilated cardiomyopathy) induced by arteriovenous anastomosis and doxorubicin administration in sheep. J Thorac Cardiovasc Surg 117:198-199

38. Chen H, Charlat O, Tartaglia LA, Woolf EA, Weng X, Ellis SJ, Lakey ND, Culpepper J, Moore KJ, Breitbart RE, Duyk GM, Tepper RI, Morgenstern JP (1996) Evidence that the diabetes gene encodes the leptin receptor: identification of a mutation in the leptin receptor gene in $\mathrm{db} / \mathrm{db}$ mice. Cell 84:491-495

39. Chen J, Chien KR (1999) Complexity in simplicity: monogenic disorders and complex cardiomyopathies. J Clin Invest 103:1483-1485. doi:10.1172/JCI7297

40. Chen Y, Daosukho C, Opii WO, Turner DM, Pierce WM, Klein JB, Vore M, Butterfield DA, St Clair DK (2006) Redox proteomic identification of oxidized cardiac proteins in adriamycintreated mice. Free Radic Biol Med 41:1470-1477. doi: 10.1016/j.freeradbiomed.2006.08.006

41. Chua SC Jr, Chung WK, Wu-Peng XS, Zhang Y, Liu SM, Tartaglia L, Leibel RL (1996) Phenotypes of mouse diabetes and rat fatty due to mutations in the $\mathrm{OB}$ (leptin) receptor. Science 271:994-996

42. Cohn JN (2002) Sympathetic nervous system in heart failure. Circulation 106:2417-2418

43. Colbert MC, Hall DG, Kimball TR, Witt SA, Lorenz JN, Kirby ML, Hewett TE, Klevitsky R, Robbins J (1997) Cardiac compartment-specific overexpression of a modified retinoic acid receptor produces dilated cardiomyopathy and congestive heart failure in transgenic mice. J Clin Invest 100:1958-1968. doi: 10.1172/JCI119727

44. Coral-Vazquez R, Cohn RD, Moore SA, Hill JA, Weiss RM, Davisson RL, Straub V, Barresi R, Bansal D, Hrstka RF, Williamson R, Campbell KP (1999) Disruption of the sarcoglycan-sarcospan complex in vascular smooth muscle: a novel mechanism for cardiomyopathy and muscular dystrophy. Cell 98:465-474

45. Creemers EE, Davis JN, Parkhurst AM, Leenders P, Dowdy KB, Hapke E, Hauet AM, Escobar PG, Cleutjens JP, Smits JF, Daemen MJ, Zile MR, Spinale FG (2003) Deficiency of TIMP-1 exacerbates LV remodeling after myocardial infarction in mice. Am J Physiol Heart Circ Physiol 284:H364-371. doi:10.1152/ ajpheart.00511.2002

46. Cunha-Neto E, Dzau VJ, Allen PD, Stamatiou D, Benvenutti L, Higuchi ML, Koyama NS, Silva JS, Kalil J, Liew CC (2005) Cardiac gene expression profiling provides evidence for cytokinopathy as a molecular mechanism in Chagas' disease cardiomyopathy. Am J Pathol 167:305-313. doi:10.1016/S00029440(10)62976-8

47. D'Angelo DD, Sakata Y, Lorenz JN, Boivin GP, Walsh RA, Liggett SB, Dorn GW 2nd (1997) Transgenic Galphaq overexpression induces cardiac contractile failure in mice. Proc Natl Acad Sci USA 94:8121-8126

48. Dahl LK, Heine M, Tassinari L (1962) Role of genetic factors in susceptibility to experimental hypertension due to chronic excess salt ingestion. Nature 194:480-482
49. Dash R, Kadambi V, Schmidt AG, Tepe NM, Biniakiewicz D, Gerst MJ, Canning AM, Abraham WT, Hoit BD, Liggett SB, Lorenz JN, Dorn GW 2nd, Kranias EG (2001) Interactions between phospholamban and beta-adrenergic drive may lead to cardiomyopathy and early mortality. Circulation 103:889-896

50. De Angelis A, Piegari E, Cappetta D, Marino L, Filippelli A, Berrino L, Ferreira-Martins J, Zheng H, Hosoda T, Rota M, Urbanek K, Kajstura J, Leri A, Rossi F, Anversa P (2010) Anthracycline cardiomyopathy is mediated by depletion of the cardiac stem cell pool and is rescued by restoration of progenitor cell function. Circulation 121:276-292. doi:10.1161/CIRCULA TIONAHA.109.895771

51. Delgado RM 3rd, Nawar MA, Zewail AM, Kar B, Vaughn WK, Wu KK, Aleksic N, Sivasubramanian N, McKay K, Mann DL, Willerson JT (2004) Cyclooxygenase-2 inhibitor treatment improves left ventricular function and mortality in a murine model of doxorubicin-induced heart failure. Circulation 109:1428-1433. doi:10.1161/01.CIR.0000121354.34067.48

52. Devi S, Kennedy RH, Joseph L, Shekhawat NS, Melchert RB, Joseph J (2006) Effect of long-term hyperhomocysteinemia on myocardial structure and function in hypertensive rats. Cardiovasc Pathol 15:75-82. doi:10.1016/j.carpath.2005.11.001

53. Dickstein K, Cohen-Solal A, Filippatos G, McMurray JJ, Ponikowski P, Poole-Wilson PA, Stromberg A, van Veldhuisen DJ, Atar D, Hoes AW, Keren A, Mebazaa A, Nieminen M, Priori SG, Swedberg K (2008) ESC guidelines for the diagnosis and treatment of acute and chronic heart failure 2008: the Task Force for the diagnosis and treatment of acute and chronic heart failure 2008 of the European Society of Cardiology. Developed in collaboration with the Heart Failure Association of the ESC (HFA) and endorsed by the European Society of Intensive Care Medicine (ESICM). Eur J Heart Fail 10:933-989. doi: 10.1016/j.ejheart.2008.08.005

54. Dodd DA, Atkinson JB, Olson RD, Buck S, Cusack BJ, Fleischer S, Boucek RJ Jr (1993) Doxorubicin cardiomyopathy is associated with a decrease in calcium release channel of the sarcoplasmic reticulum in a chronic rabbit model. J Clin Invest 91:1697-1705. doi:10.1172/JCI116379

55. Doi R, Masuyama T, Yamamoto K, Doi Y, Mano T, Sakata Y, Ono K, Kuzuya T, Hirota S, Koyama T, Miwa T, Hori M (2000) Development of different phenotypes of hypertensive heart failure: systolic versus diastolic failure in Dahl salt-sensitive rats. J Hypertens 18:111-120

56. Drolet MC, Lachance D, Plante E, Roussel E, Couet J, Arsenault M (2006) Gender-related differences in left ventricular remodeling in chronic severe aortic valve regurgitation in rats. J Heart Valve Dis 15:345-351

57. Du XJ, Autelitano DJ, Dilley RJ, Wang B, Dart AM, Woodcock EA (2000) beta(2)-adrenergic receptor overexpression exacerbates development of heart failure after aortic stenosis. Circulation 101:71-77

58. Du XJ, Gao XM, Wang B, Jennings GL, Woodcock EA, Dart AM (2000) Age-dependent cardiomyopathy and heart failure phenotype in mice overexpressing beta(2)-adrenergic receptors in the heart. Cardiovasc Res 48:448-454

59. Du XJ, Vincan E, Woodcock DM, Milano CA, Dart AM, Woodcock EA (1996) Response to cardiac sympathetic activation in transgenic mice overexpressing beta 2-adrenergic receptor. Am J Physiol 271:H630-H636

60. Dubi S, Arbel Y (2010) Large animal models for diastolic dysfunction and diastolic heart failure-a review of the literature. Cardiovasc Pathol 19:147-152. doi:10.1016/j.carpath.2008.12. 008

61. Ducharme A, Frantz S, Aikawa M, Rabkin E, Lindsey M, Rohde LE, Schoen FJ, Kelly RA, Werb Z, Libby P, Lee RT (2000) 
Targeted deletion of matrix metalloproteinase-9 attenuates left ventricular enlargement and collagen accumulation after experimental myocardial infarction. J Clin Invest 106:55-62. doi:10.1172/JCI8768

62. El-Demerdash E, Awad AS, Taha RM, El-Hady AM, SayedAhmed MM (2005) Probucol attenuates oxidative stress and energy decline in isoproterenol-induced heart failure in rat. Pharmacol Res 51:311-318. doi:10.1016/j.phrs.2004.10.002

63. Engelhardt S, Boknik P, Keller U, Neumann J, Lohse MJ, Hein L (2001) Early impairment of calcium handling and altered expression of junctin in hearts of mice overexpressing the beta1adrenergic receptor. FASEB J 15:2718-2720. doi:10.1096/fj.010107fje

64. Engelhardt S, Hein L, Dyachenkow V, Kranias EG, Isenberg G, Lohse MJ (2004) Altered calcium handling is critically involved in the cardiotoxic effects of chronic beta-adrenergic stimulation. Circulation 109:1154-1160. doi:10.1161/01.CIR.0000117254. 68497.39

65. Engelhardt S, Hein L, Wiesmann F, Lohse MJ (1999) Progressive hypertrophy and heart failure in beta1-adrenergic receptor transgenic mice. Proc Natl Acad Sci USA 96:7059-7064

66. Escobales N, Crespo MJ (2008) Early pathophysiological alterations in experimental cardiomyopathy: the Syrian cardiomyopathic hamster. P R Health Sci J 27:307-314

67. Esposito G, Rapacciuolo A, Naga Prasad SV, Takaoka H, Thomas SA, Koch WJ, Rockman HA (2002) Genetic alterations that inhibit in vivo pressure-overload hypertrophy prevent cardiac dysfunction despite increased wall stress. Circulation 105: $85-92$

68. Fairweather D, Kaya Z, Shellam GR, Lawson CM, Rose NR (2001) From infection to autoimmunity. J Autoimmun 16:175186. doi:10.1006/jaut.2000.0492

69. Falcao-Pires I, Palladini G, Goncalves N, van der Velden J, Moreira-Goncalves D, Miranda-Silva D, Salinaro F, Paulus WJ, Niessen HW, Perlini S, Leite-Moreira AF (2011) Distinct mechanisms for diastolic dysfunction in diabetes mellitus and chronic pressure-overload. Basic Res Cardiol 106:801-814. doi: 10.1007/s00395-011-0184-X

70. Feldman AM, Weinberg EO, Ray PE, Lorell BH (1993) Selective changes in cardiac gene expression during compensated hypertrophy and the transition to cardiac decompensation in rats with chronic aortic banding. Circ Res 73:184-192

71. Finck BN, Lehman JJ, Leone TC, Welch MJ, Bennett MJ, Kovacs A, Han X, Gross RW, Kozak R, Lopaschuk GD, Kelly DP (2002) The cardiac phenotype induced by PPARalpha overexpression mimics that caused by diabetes mellitus. J Clin Invest 109:121-130. doi:10.1172/JCI14080

72. Francis GS, Tang WH (2003) Pathophysiology of congestive heart failure. Rev Cardiovasc Med 4(Suppl 2):S14-S20

73. Freeman RH, Davis JO, Watkins BE, Stephens GA, DeForrest JM (1979) Effects of continuous converting enzyme blockade on renovascular hypertension in the rat. Am J Physiol 236:F21-F24

74. Fu M, Matoba M, Liang QM, Sjogren KG, Hjalmarson A (1994) Properties of G-protein modulated receptor-adenylyl cyclase system in myocardium of spontaneously hypertensive rats treated with adriamycin. Int J Cardiol 44:9-18

75. Fujihira S, Yamamoto T, Matsumoto M, Yoshizawa K, Oishi Y, Fujii T, Noguchi H, Mori H (1993) The high incidence of atrial thrombosis in mice given doxorubicin. Toxicol Pathol 21:362-368

76. Gao XM, Dart AM, Dewar E, Jennings G, Du XJ (2000) Serial echocardiographic assessment of left ventricular dimensions and function after myocardial infarction in mice. Cardiovasc Res 45:330-338

77. Garcia R, Diebold S (1990) Simple, rapid, and effective method of producing aortocaval shunts in the rat. Cardiovasc Res 24: $430-432$
78. Gaudin PB, Hruban RH, Beschorner WE, Kasper EK, Olson JL, Baughman KL, Hutchins GM (1993) Myocarditis associated with doxorubicin cardiotoxicity. Am J Clin Pathol 100:158-163

79. Gehrmann J, Frantz S, Maguire CT, Vargas M, Ducharme A, Wakimoto H, Lee RT, Berul CI (2001) Electrophysiological characterization of murine myocardial ischemia and infarction. Basic Res Cardiol 96:237-250

80. Georgakopoulos D, Mitzner WA, Chen CH, Byrne BJ, Millar HD, Hare JM, Kass DA (1998) In vivo murine left ventricular pressure-volume relations by miniaturized conductance micromanometry. Am J Physiol 274:H1416-H1422

81. Goldblatt H, Lynch J, Hanzal RF, Summerville WW (1934) Studies on Experimental Hypertension : I. The production of persistent elevation of systolic blood pressure by means of renal ischemia. J Exp Med 59:347-379

82. Gomez AM, Valdivia HH, Cheng H, Lederer MR, Santana LF, Cannell MB, McCune SA, Altschuld RA, Lederer WJ (1997) Defective excitation-contraction coupling in experimental cardiac hypertrophy and heart failure. Science 276:800-806

83. Goser S, Andrassy M, Buss SJ, Leuschner F, Volz CH, Ottl R, Zittrich S, Blaudeck N, Hardt SE, Pfitzer G, Rose NR, Katus HA, Kaya Z (2006) Cardiac troponin I but not cardiac troponin $\mathrm{T}$ induces severe autoimmune inflammation in the myocardium. Circulation 114:1693-1702. doi:10.1161/CIRCULATIONAHA. 106.635664

84. Goto Y, Suzuki K, Ono T, Sasaki M, Toyota T (1988) Development of diabetes in the non-obese NIDDM rat (GK rat). Adv Exp Med Biol 246:29-31

85. Gould KE, Taffet GE, Michael LH, Christie RM, Konkol DL, Pocius JS, Zachariah JP, Chaupin DF, Daniel SL, Sandusky GE Jr, Hartley CJ, Entman ML (2002) Heart failure and greater infarct expansion in middle-aged mice: a relevant model for postinfarction failure. Am J Physiol Heart Circ Physiol 282:H615-H621. doi:10.1152/ajpheart.00206.2001

86. Grady RM, Teng H, Nichol MC, Cunningham JC, Wilkinson RS, Sanes JR (1997) Skeletal and cardiac myopathies in mice lacking utrophin and dystrophin: a model for Duchenne muscular dystrophy. Cell 90:729-738

87. Greer JJ, Ware DP, Lefer DJ (2006) Myocardial infarction and heart failure in the $\mathrm{db} / \mathrm{db}$ diabetic mouse. Am J Physiol Heart Circ Physiol 290:H146-153. doi:10.1152/ajpheart.00583.2005

88. Grimm D, Elsner D, Schunkert H, Pfeifer M, Griese D, Bruckschlegel G, Muders F, Riegger GA, Kromer EP (1998) Development of heart failure following isoproterenol administration in the rat: role of the renin-angiotensin system. Cardiovasc Res 37:91-100

89. Grobe JL, Mecca AP, Mao H, Katovich MJ (2006) Chronic angiotensin-(1-7) prevents cardiac fibrosis in DOCA-salt model of hypertension. Am J Physiol Heart Circ Physiol 290:H24172423. doi:10.1152/ajpheart.01170.2005

90. Gruver CL, DeMayo F, Goldstein MA, Means AR (1993) Targeted developmental overexpression of calmodulin induces proliferative and hypertrophic growth of cardiomyocytes in transgenic mice. Endocrinology 133:376-388

91. Haghighi K, Schmidt AG, Hoit BD, Brittsan AG, Yatani A, Lester JW, Zhai J, Kimura Y, Dorn GW 2nd, MacLennan DH, Kranias EG (2001) Superinhibition of sarcoplasmic reticulum function by phospholamban induces cardiac contractile failure. J Biol Chem 276:24145-24152. doi:10.1074/jbc.M102403200

92. Halapas A, Papalois A, Stauropoulou A, Philippou A, Pissimissis N, Chatzigeorgiou A, Kamper E, Koutsilieris M (2008) In vivo models for heart failure research. In Vivo 22:767780

93. Halapas A, Pissimissis N, Lembessis P, Rizos I, Rigopoulos AG, Kremastinos DT, Koutsilieris M (2008) Molecular diagnosis of the viral component in cardiomyopathies: pathophysiological, 
clinical and therapeutic implications. Expert Opin Ther Targets 12:821-836. doi:10.1517/14728222.12.7.821

94. Hara M, Ono K, Hwang MW, Iwasaki A, Okada M, Nakatani K, Sasayama S, Matsumori A (2002) Evidence for a role of mast cells in the evolution to congestive heart failure. J Exp Med 195:375-381

95. Harding VB, Jones LR, Lefkowitz RJ, Koch WJ, Rockman HA (2001) Cardiac beta ARK1 inhibition prolongs survival and augments beta blocker therapy in a mouse model of severe heart failure. Proc Natl Acad Sci USA 98:5809-5814. doi:10.1073/ pnas.091102398

96. Hayashidani S, Tsutsui H, Ikeuchi M, Shiomi T, Matsusaka H, Kubota T, Imanaka-Yoshida K, Itoh T, Takeshita A (2003) Targeted deletion of MMP-2 attenuates early LV rupture and late remodeling after experimental myocardial infarction. Am J Physiol Heart Circ Physiol 285:H1229-1235. doi:10.1152/ ajpheart.00207.2003

97. He H, Giordano FJ, Hilal-Dandan R, Choi DJ, Rockman HA, McDonough PM, Bluhm WF, Meyer M, Sayen MR, Swanson E, Dillmann WH (1997) Overexpression of the rat sarcoplasmic reticulum $\mathrm{Ca}^{+}{ }^{+}$ATPase gene in the heart of transgenic mice accelerates calcium transients and cardiac relaxation. J Clin Invest 100:380-389. doi:10.1172/JCI119544

98. Herman EH, Ferrans VJ (1998) Preclinical animal models of cardiac protection from anthracycline-induced cardiotoxicity. Semin Oncol 25:15-21

99. Hessel MH, Steendijk P, den Adel B, Schutte CI, van der Laarse A (2006) Characterization of right ventricular function after monocrotaline-induced pulmonary hypertension in the intact rat. Am J Physiol Heart Circ Physiol 291:H2424-2430. doi:10.1152/ ajpheart.00369.2006

100. Heyen JR, Blasi ER, Nikula K, Rocha R, Daust HA, Frierdich G, Van Vleet JF, De Ciechi P, McMahon EG, Rudolph AE (2002) Structural, functional, and molecular characterization of the SHHF model of heart failure. Am J Physiol Heart Circ Physiol 283:H1775-H1784. doi:10.1152/ajpheart.00305.2002

101. Heymans S, Hirsch E, Anker SD, Aukrust P, Balligand JL, Cohen-Tervaert JW, Drexler H, Filippatos G, Felix SB, Gullestad L, Hilfiker-Kleiner D, Janssens S, Latini R, Neubauer G, Paulus WJ, Pieske B, Ponikowski P, Schroen B, Schultheiss HP, Tschope C, Van Bilsen M, Zannad F, McMurray J, Shah AM (2009) Inflammation as a therapeutic target in heart failure? A scientific statement from the Translational Research Committee of the Heart Failure Association of the European Society of Cardiology. Eur J Heart Fail 11:119-129. doi:10.1093/eurjhf/ hfn043

102. Heymans S, Pauschinger M, De Palma A, Kallwellis-Opara A, Rutschow S, Swinnen M, Vanhoutte D, Gao F, Torpai R, Baker AH, Padalko E, Neyts J, Schultheiss HP, Van de Werf F, Carmeliet P, Pinto YM (2006) Inhibition of urokinase-type plasminogen activator or matrix metalloproteinases prevents cardiac injury and dysfunction during viral myocarditis. Circulation 114:565-573. doi:10.1161/CIRCULATIONAHA.105.591032

103. Hibbs RG, Ferrans VJ, Walsh JJ, Burch GE (1965) Electron microscopic observations on lysosomes and related cytoplasmic components of normal and pathological cardiac muscle. Anat Rec 153:173-185

104. Hirono S, Islam MO, Nakazawa M, Yoshida Y, Kodama M, Shibata A, Izumi T, Imai S (1997) Expression of inducible nitric oxide synthase in rat experimental autoimmune myocarditis with special reference to changes in cardiac hemodynamics. Circ Res 80:11-20

105. Hirota H, Chen J, Betz UA, Rajewsky K, Gu Y, Ross J Jr, Muller W, Chien KR (1999) Loss of a gp130 cardiac muscle cell survival pathway is a critical event in the onset of heart failure during biomechanical stress. Cell 97:189-198
106. Hirota H, Yoshida K, Kishimoto T, Taga T (1995) Continuous activation of gp130, a signal-transducing receptor component for interleukin 6-related cytokines, causes myocardial hypertrophy in mice. Proc Natl Acad Sci USA 92:4862-4866

107. Holycross BJ, Summers BM, Dunn RB, McCune SA (1997) Plasma renin activity in heart failure-prone SHHF/Mcc-facp rats. Am J Physiol 273:H228-H233

108. Homburger F (1979) Myopathy of hamster dystrophy: history and morphologic aspects. Ann N Y Acad Sci 317:1-17

109. Homburger F, Baker JR, Nixon CW, Wilgram G (1962) New hereditary disease of Syrian hamsters. Primary, generalized polymyopathy and cardiac necrosis. Arch Intern Med 110:660-662

110. Homburger F, Nixon CW, Eppenberger M, Baker JR (1966) Hereditary myopathy in the Syrian hamster: studies on pathogenesis. Ann N Y Acad Sci 138:14-27

111. Hu P, Zhang D, Swenson L, Chakrabarti G, Abel ED, Litwin SE (2003) Minimally invasive aortic banding in mice: effects of altered cardiomyocyte insulin signaling during pressure overload. Am J Physiol Heart Circ Physiol 285:H1261-1269. doi: 10.1152/ajpheart.00108.2003

112. Huang WY, Aramburu J, Douglas PS, Izumo S (2000) Transgenic expression of green fluorescence protein can cause dilated cardiomyopathy. Nat Med 6:482-483. doi:10.1038/74914

113. Hunter EG, Hughes V, White J (1984) Cardiomyopathic hamsters, CHF 146 and CHF 147: a preliminary study. Can J Physiol Pharmacol 62:1423-1428

114. Hunter JJ, Tanaka N, Rockman HA, Ross J Jr, Chien KR (1995) Ventricular expression of a MLC-2v-ras fusion gene induces cardiac hypertrophy and selective diastolic dysfunction in transgenic mice. J Biol Chem 270:23173-23178

115. Hwang GS, Oh KS, Koo HN, Seo HW, You KH, Lee BH (2006) Effects of KR-31378, a novel ATP-sensitive potassium channel activator, on hypertrophy of $\mathrm{H} 9 \mathrm{c} 2$ cells and on cardiac dysfunction in rats with congestive heart failure. Eur $\mathrm{J}$ Pharmacol 540:131-138. doi:10.1016/j.ejphar.2006.04.031

116. Ichihara S, Obata K, Yamada Y, Nagata K, Noda A, Ichihara G, Yamada A, Kato T, Izawa H, Murohara T, Yokota M (2006) Attenuation of cardiac dysfunction by a PPAR-alpha agonist is associated with down-regulation of redox-regulated transcription factors. J Mol Cell Cardiol 41:318-329. doi:10.1016/ j.yjmcc.2006.05.013

117. Ikegami T, Suzuki Y, Shimizu T, Isono K, Koseki H, Shirasawa $\mathrm{T}$ (2002) Model mice for tissue-specific deletion of the manganese superoxide dismutase (MnSOD) gene. Biochem Biophys Res Commun 296:729-736

118. Ingalls AM, Dickie MM, Snell GD (1950) Obese, a new mutation in the house mouse. J Hered 41:317-318

119. Inoko M, Kihara Y, Morii I, Fujiwara H, Sasayama S (1994) Transition from compensatory hypertrophy to dilated, failing left ventricles in Dahl salt-sensitive rats. Am J Physiol 267: $\mathrm{H} 2471-\mathrm{H} 2482$

120. Intengan HD, Park JB, Schiffrin EL (1999) Blood pressure and small arteries in DOCA-salt-treated genetically AVP-deficient rats: role of endothelin. Hypertension 34:907-913

121. Ishibashi S, Goldstein JL, Brown MS, Herz J, Burns DK (1994) Massive xanthomatosis and atherosclerosis in cholesterol-fed low density lipoprotein receptor-negative mice. J Clin Invest 93:1885-1893. doi:10.1172/JCI117179

122. Ito H, Torii M, Suzuki T (1995) Decreased superoxide dismutase activity and increased superoxide anion production in cardiac hypertrophy of spontaneously hypertensive rats. Clin Exp Hypertens 17:803-816

123. Ito K, Yan X, Feng X, Manning WJ, Dillmann WH, Lorell BH (2001) Transgenic expression of sarcoplasmic reticulum $\mathrm{Ca}\left(2^{+}\right)$ ATPase modifies the transition from hypertrophy to early heart failure. Circ Res 89:422-429 
124. Iwase M, Bishop SP, Uechi M, Vatner DE, Shannon RP, Kudej RK, Wight DC, Wagner TE, Ishikawa Y, Homcy CJ, Vatner SF (1996) Adverse effects of chronic endogenous sympathetic drive induced by cardiac GS alpha overexpression. Circ Res 78:517524

125. Janssen SW, Martens GJ, Sweep CG, Ross HA, Hermus AR (1999) In Zucker diabetic fatty rats plasma leptin levels are correlated with plasma insulin levels rather than with body weight. Horm Metab Res 31:610-615. doi:10.1055/s-2007-97 8806

126. Jasmin G, Eu HY (1979) Cardiomyopathy of hamster dystrophy. Ann N Y Acad Sci 317:46-58

127. Jeong D, Cha H, Kim E, Kang M, Yang DK, Kim JM, Yoon PO, Oh JG, Bernecker OY, Sakata S, Le TT, Cui L, Lee YH, Kim do H, Woo SH, Liao R, Hajjar RJ, Park WJ (2006) PICOT inhibits cardiac hypertrophy and enhances ventricular function and cardiomyocyte contractility. Circ Res 99:307-314. doi:10.1161/ 01.RES.0000234780.06115.2c

128. Jones LR, Suzuki YJ, Wang W, Kobayashi YM, Ramesh V, Franzini-Armstrong C, Cleemann L, Morad M (1998) Regulation of $\mathrm{Ca} 2+$ signaling in transgenic mouse cardiac myocytes overexpressing calsequestrin. J Clin Invest 101:1385-1393. doi: $10.1172 / \mathrm{JCI} 1362$

129. Joseph J, Joseph L, Shekhawat NS, Devi S, Wang J, Melchert RB, Hauer-Jensen M, Kennedy RH (2003) Hyperhomocysteinemia leads to pathological ventricular hypertrophy in normotensive rats. Am J Physiol Heart Circ Physiol 285:H679-686. doi:10.1152/ajpheart.00145.2003

130. Joseph J, Washington A, Joseph L, Koehler L, Fink LM, HauerJensen M, Kennedy RH (2002) Hyperhomocysteinemia leads to adverse cardiac remodeling in hypertensive rats. Am J Physiol Heart Circ Physiol 283:H2567-2574. doi:10.1152/ajpheart. 00475.2002

131. Junhong W, Jing Y, Jizheng M, Shushu Z, Xiangjian C, Hengfang W, Di Y, Jinan Z (2008) Proteomic analysis of left ventricular diastolic dysfunction hearts in renovascular hypertensive rats. Int J Cardiol 127:198-207. doi:10.1016/j.ijcard. 2007.07.003

132. Katholi RE, Naftilan AJ, Oparil S (1980) Importance of renal sympathetic tone in the development of DOCA-salt hypertension in the rat. Hypertension 2:266-273

133. Kawano K, Hirashima T, Mori S, Saitoh Y, Kurosumi M, Natori $\mathrm{T}$ (1992) Spontaneous long-term hyperglycemic rat with diabetic complications-Otsuka Long-Evans Tokushima Fatty (Oletf) strain. Diabetes 41:1422-1428

134. Kawase Y, Ly HQ, Prunier F, Lebeche D, Shi Y, Jin H, Hadri L, Yoneyama R, Hoshino K, Takewa Y, Sakata S, Peluso R, Zsebo K, Gwathmey JK, Tardif JC, Tanguay JF, Hajjar RJ (2008) Reversal of cardiac dysfunction after long-term expression of SERCA2a by gene transfer in a pre-clinical model of heart failure. J Am Coll Cardiol 51:1112-1119. doi:10.1016/j.jacc. 2007.12.014

135. Kay JM, Smith P, Heath D (1969) Electron microscopy of Crotalaria pulmonary hypertension. Thorax 24:511-526

136. Kazumi T, Odaka H, Hozumi T, Ishida Y, Amano N, Yoshino G (1997) Effects of dietary fructose or glucose on triglyceride production and lipogenic enzyme activities in the liver of Wistar fatty rats, an animal model of NIDDM. Endocr J 44:239-245

137. Kim S, Yoshiyama M, Izumi Y, Kawano H, Kimoto M, Zhan Y, Iwao H (2001) Effects of combination of ACE inhibitor and angiotensin receptor blocker on cardiac remodeling, cardiac function, and survival in rat heart failure. Circulation 103:148154

138. Kiss E, Ball NA, Kranias EG, Walsh RA (1995) Differential changes in cardiac phospholamban and sarcoplasmic reticular $\mathrm{Ca}\left(2^{+}\right)$-ATPase protein levels. Effects on $\mathrm{Ca} 2+$ transport and mechanics in compensated pressure-overload hypertrophy and congestive heart failure. Circ Res 77:759-764

139. Klotz S, Hay I, Zhang G, Maurer M, Wang J, Burkhoff D (2006) Development of heart failure in chronic hypertensive Dahl rats: focus on heart failure with preserved ejection fraction. Hypertension 47:901-911. doi:10.1161/01.HYP.0000215579.81408.8e

140. Koch WJ, Rockman HA, Samama P, Hamilton RA, Bond RA, Milano CA, Lefkowitz RJ (1995) Cardiac function in mice overexpressing the beta-adrenergic receptor kinase or a beta ARK inhibitor. Science 268:1350-1353

141. Konduracka E, Gackowski A, Rostoff P, Galicka-Latala D, Frasik W, Piwowarska W (2007) Diabetes-specific cardiomyopathy in type 1 diabetes mellitus: no evidence for its occurrence in the era of intensive insulin therapy. Eur Heart $\mathrm{J}$ 28:2465-2471. doi:10.1093/eurheartj/ehm361

142. Krzeminski TF, Nozynski JK, Grzyb J, Porc M (2008) Widespread myocardial remodeling after acute myocardial infarction in rat. Features for heart failure progression. Vascul Pharmacol 48:100-108. doi:10.1016/j.vph.2008.01.002

143. Kubota T, McTiernan CF, Frye CS, Slawson SE, Lemster BH, Koretsky AP, Demetris AJ, Feldman AM (1997) Dilated cardiomyopathy in transgenic mice with cardiac-specific overexpression of tumor necrosis factor-alpha. Circ Res 81:627-635

144. Kuhlmann MT, Kirchhof P, Klocke R, Hasib L, Stypmann J, Fabritz L, Stelljes M, Tian W, Zwiener M, Mueller M, Kienast J, Breithardt G, Nikol S (2006) G-CSF/SCF reduces inducible arrhythmias in the infarcted heart potentially via increased connexin43 expression and arteriogenesis. J Exp Med 203:8797. doi:10.1084/jem.20051151

145. Kumar A, Crawford K, Close L, Madison M, Lorenz J, Doetschman T, Pawlowski S, Duffy J, Neumann J, Robbins J, Boivin GP, O'Toole BA, Lessard JL (1997) Rescue of cardiac alpha-actin-deficient mice by enteric smooth muscle gammaactin. Proc Natl Acad Sci USA 94:4406-4411

146. Kurrelmeyer KM, Michael LH, Baumgarten G, Taffet GE, Peschon JJ, Sivasubramanian N, Entman ML, Mann DL (2000) Endogenous tumor necrosis factor protects the adult cardiac myocyte against ischemic-induced apoptosis in a murine model of acute myocardial infarction. Proc Natl Acad Sci U S A 97:5456-5461. doi:10.1073/pnas.070036297

147. Kuwajima I, Kardon MB, Pegram BL, Sesoko S, Frohlich ED (1982) Regression of left ventricular hypertrophy in two-kidney, one clip Goldblatt hypertension. Hypertension 4:113-118

148. Langenickel T, Pagel I, Hohnel K, Dietz R, Willenbrock R (2000) Differential regulation of cardiac ANP and BNP mRNA in different stages of experimental heart failure. Am J Physiol Heart Circ Physiol 278:H1500-H1506

149. Lebrecht D, Kokkori A, Ketelsen UP, Setzer B, Walker UA (2005) Tissue-specific mtDNA lesions and radical-associated mitochondrial dysfunction in human hearts exposed to doxorubicin. J Pathol 207:436-444. doi:10.1002/path.1863

150. Leenen FH, de Jong W (1975) Plasma renin and sodium balance during development of moderate and severe renal hypertension in rats. Circ Res 36:179-186

151. Lefrak EA, Pitha J, Rosenheim S, Gottlieb JA (1973) A clinicopathologic analysis of adriamycin cardiotoxicity. Cancer 32:302-314

152. Leite-Moreira AF (2006) Current perspectives in diastolic dysfunction and diastolic heart failure. Heart 92:712-718. doi: 10.1136/hrt.2005.062950

153. Li JM, Yao ZF, Zou YZ, Ge JB, Guan AL, Wu J, Mi SL, Liang YY, Ma Z (2011) The therapeutic potential of G-CSF in pressure overload induced ventricular reconstruction and heart failure in mice. Mol Biol Rep doi:10.1007/s11033-011-0703-8

154. Li L, Chu Y, Fink GD, Engelhardt JF, Heistad DD, Chen AF (2003) Endothelin-1 stimulates arterial VCAM-1 expression via 
NADPH oxidase-derived superoxide in mineralocorticoid hypertension. Hypertension 42:997-1003. doi:10.1161/01.HYP. 0000095980.43859 .59

155. Li Y, Takemura G, Kosai K, Takahashi T, Okada H, Miyata S, Yuge K, Nagano S, Esaki M, Khai NC, Goto K, Mikami A, Maruyama R, Minatoguchi S, Fujiwara T, Fujiwara H (2004) Critical roles for the Fas/Fas ligand system in postinfarction ventricular remodeling and heart failure. Circ Res 95:627-636. doi:10.1161/01.RES.0000141528.54850.bd

156. Li YY, Feldman AM (2001) Matrix metalloproteinases in the progression of heart failure: potential therapeutic implications. Drugs 61:1239-1252

157. Li Z, Bing OH, Long X, Robinson KG, Lakatta EG (1997) Increased cardiomyocyte apoptosis during the transition to heart failure in the spontaneously hypertensive rat. Am J Physiol 272:H2313-H2319

158. Li Z, Tran TT, Ma JY, O'Young G, Kapoun AM, Chakravarty S, Dugar S, Schreiner G, Protter AA (2004) p38 alpha mitogenactivated protein kinase inhibition improves cardiac function and reduces myocardial damage in isoproterenol-induced acute myocardial injury in rats. J Cardiovasc Pharmacol 44:486-492.

159. Liggett SB, Tepe NM, Lorenz JN, Canning AM, Jantz TD, Mitarai S, Yatani A, Dorn GW 2nd (2000) Early and delayed consequences of beta(2)-adrenergic receptor overexpression in mouse hearts: critical role for expression level. Circulation 101: $1707-1714$

160. Lim CC, Zuppinger C, Guo X, Kuster GM, Helmes M, Eppenberger HM, Suter TM, Liao R, Sawyer DB (2004) Anthracyclines induce calpain-dependent titin proteolysis and necrosis in cardiomyocytes. J Biol Chem 279:8290-8299. doi: 10.1074/jbc.M308033200

161. Ling H, Zhang T, Pereira L, Means CK, Cheng H, Gu Y, Dalton ND, Peterson KL, Chen J, Bers D, Heller Brown J (2009) Requirement for $\mathrm{Ca} 2+/$ calmodulin-dependent kinase II in the transition from pressure overload-induced cardiac hypertrophy to heart failure in mice. J Clin Invest 119:1230-1240. doi: 10.1172/JCI38022

162. Litwin SE, Katz SE, Weinberg EO, Lorell BH, Aurigemma GP, Douglas PS (1995) Serial echocardiographic-Doppler assessment of left ventricular geometry and function in rats with pressure-overload hypertrophy. Chronic angiotensin-converting enzyme inhibition attenuates the transition to heart failure. Circulation 91:2642-2654

163. Liu P, Penninger J, Aitken K, Sole M, Mak T (1995) The role of transgenic knockout models in defining the pathogenesis of viral heart disease. Eur Heart J 16 Suppl O:25-27

164. Liu YH, Yang XP, Nass O, Sabbah HN, Peterson E, Carretero OA (1997) Chronic heart failure induced by coronary artery ligation in Lewis inbred rats. Am J Physiol 272:H722-H727

165. Liu Z, Hilbelink DR, Crockett WB, Gerdes AM (1991) Regional changes in hemodynamics and cardiac myocyte size in rats with aortocaval fistulas. 1. Developing and established hypertrophy. Circ Res 69:52-58

166. Lloyd-Jones D, Adams RJ, Brown TM, Carnethon M, Dai S, De Simone G, Ferguson TB, Ford E, Furie K, Gillespie C, Go A, Greenlund K, Haase N, Hailpern S, Ho PM, Howard V, Kissela B, Kittner S, Lackland D, Lisabeth L, Marelli A, McDermott MM, Meigs J, Mozaffarian D, Mussolino M, Nichol G, Roger VL, Rosamond W, Sacco R, Sorlie P, Thom T, WasserthielSmoller S, Wong ND, Wylie-Rosett J (2010) Heart disease and stroke statistics-2010 update: a report from the American Heart Association. Circulation 121:e46-e215. doi:10.1161/CIRCULA TIONAHA.109.192667

167. London B, Baker LC, Lee JS, Shusterman V, Choi BR, Kubota T, McTiernan CF, Feldman AM, Salama G (2003) Calciumdependent arrhythmias in transgenic mice with heart failure. Am
J Physiol Heart Circ Physiol 284:H431-441. doi:10.1152/ajp heart.00431.2002

168. Lou H, Danelisen I, Singal PK (2004) Cytokines are not upregulated in adriamycin-induced cardiomyopathy and heart failure. J Mol Cell Cardiol 36:683-690. doi:10.1016/j.yjmcc. 2004.03.004

169. Luo J, Fujikura K, Homma S, Konofagou EE (2007) Myocardial elastography at both high temporal and spatial resolution for the detection of infarcts. Ultrasound Med Biol 33:1206-1223. doi: 10.1016/j.ultrasmedbio.2007.01.019

170. Luo W, Grupp IL, Harrer J, Ponniah S, Grupp G, Duffy JJ, Doetschman T, Kranias EG (1994) Targeted ablation of the phospholamban gene is associated with markedly enhanced myocardial contractility and loss of beta-agonist stimulation. Circ Res 75:401-409

171. Lygate CA, Schneider JE, Hulbert K, ten Hove M, SebagMontefiore LM, Cassidy PJ, Clarke K, Neubauer S (2006) Serial high resolution 3D-MRI after aortic banding in mice: band internalization is a source of variability in the hypertrophic response. Basic Res Cardiol 101:8-16. doi:10.1007/s00395005-0546-3

172. MacLennan DH, Kranias EG (2003) Phospholamban: a crucial regulator of cardiac contractility. Nat Rev Mol Cell Biol 4:566577. doi:10.1038/nrm1151

173. Maier LS, Wahl-Schott C, Horn W, Weichert S, Pagel C, Wagner S, Dybkova N, Muller OJ, Nabauer M, Franz WM, Pieske B (2005) Increased SR Ca2+ cycling contributes to improved contractile performance in SERCA2a-overexpressing transgenic rats. Cardiovasc Res 67:636-646. doi:10.1016/j. cardiores.2005.05.006

174. Mann DL (2002) Inflammatory mediators and the failing heart: past, present, and the foreseeable future. Circ Res 91:988-998

175. Manning RD Jr, Meng S, Tian N (2003) Renal and vascular oxidative stress and salt-sensitivity of arterial pressure. Acta Physiol Scand 179:243-250

176. Marian AJ, Roberts R (2001) The molecular genetic basis for hypertrophic cardiomyopathy. J Mol Cell Cardiol 33:655-670. doi:10.1006/jmcc. 2001.1340

177. Matsumori A, Kawai C (1982) An experimental model for congestive heart failure after encephalomyocarditis virus myocarditis in mice. Circulation 65:1230-1235

178. Matsumori A, Sasayama S (1995) Immunomodulating agents for the management of heart failure with myocarditis and cardiomyopathy-lessons from animal experiments. Eur Heart J 16 Suppl O:140-143

179. Matsumura Y, Hashimoto N, Taira S, Kuro T, Kitano R, Ohkita M, Opgenorth TJ, Takaoka M (1999) Different contributions of endothelin-A and endothelin-B receptors in the pathogenesis of deoxycorticosterone acetate-salt-induced hypertension in rats. Hypertension 33:759-765

180. McCully JD, Jandreski MA, Liew J, Sole MJ, Liew CC (1987) Construction of cosmid genomic libraries for the normal and myopathic Syrian hamsters. Biochem Cell Biol 65:9971000

181. McMurray J, Pfeffer MA (2002) New therapeutic options in congestive heart failure: Part I. Circulation 105:2099-2106

182. McMurray J, Pfeffer MA (2002) New therapeutic options in congestive heart failure: Part II. Circulation 105:2223-2228

183. Mende U, Kagen A, Cohen A, Aramburu J, Schoen FJ, Neer EJ (1998) Transient cardiac expression of constitutively active Galphaq leads to hypertrophy and dilated cardiomyopathy by calcineurin-dependent and independent pathways. Proc Natl Acad Sci USA 95:13893-13898

184. Mendez GF, Cowie MR (2001) The epidemiological features of heart failure in developing countries: a review of the literature. Int J Cardiol 80:213-219 
185. Menna P, Recalcati S, Cairo G, Minotti G (2007) An introduction to the metabolic determinants of anthracycline cardiotoxicity. Cardiovasc Toxicol 7:80-85. doi:10.1007/s12012-0070011-7

186. Mering JV MO (1889) Diabetes mellitus nach Pankreasextirpation. Centralblatt fü $r$ klinische Medicin, Leipzig 10:383

187. Michael LH, Entman ML, Hartley CJ, Youker KA, Zhu J, Hall SR, Hawkins HK, Berens K, Ballantyne CM (1995) Myocardial ischemia and reperfusion: a murine model. Am J Physiol 269: H2147-H2154

188. Michael O’Donnell J, Narayan P, Bailey MQ, Abduljalil AM, Altschuld RA, McCune SA, Robitaille PM (1998) 31P-NMR analysis of congestive heart failure in the SHHF/Mcc-facp rat heart. J Mol Cell Cardiol 30:235-241. doi:10.1006/jmcc.1997. 0587

189. Mihm MJ, Yu F, Weinstein DM, Reiser PJ, Bauer JA (2002) Intracellular distribution of peroxynitrite during doxorubicin cardiomyopathy: evidence for selective impairment of myofibrillar creatine kinase. Br J Pharmacol 135:581-588. doi: 10.1038/sj.bjp.0704495

190. Milano CA, Allen LF, Dolber PC, Johnson TD, Rockman HA, Bond RA, Lefkowitz RJ (1995) Marked enhancement in myocardial function resulting from overexpression of a human betaadrenergic receptor gene. J Thorac Cardiovasc Surg 109:236-241

191. Milano CA, Dolber PC, Rockman HA, Bond RA, Venable ME, Allen LF, Lefkowitz RJ (1994) Myocardial expression of a constitutively active alpha $1 \mathrm{~B}$-adrenergic receptor in transgenic mice induces cardiac hypertrophy. Proc Natl Acad Sci USA 91:10109-10113

192. Milner DJ, Weitzer G, Tran D, Bradley A, Capetanaki Y (1996) Disruption of muscle architecture and myocardial degeneration in mice lacking desmin. J Cell Biol 134:1255-1270

193. Minamisawa S, Hoshijima M, Chu G, Ward CA, Frank K, Gu Y, Martone ME, Wang Y, Ross J Jr, Kranias EG, Giles WR, Chien KR (1999) Chronic phospholamban-sarcoplasmic reticulum calcium ATPase interaction is the critical calcium cycling defect in dilated cardiomyopathy. Cell 99:313-322

194. Mitchell GF, Pfeffer JM, Pfeffer MA (1997) The transition to failure in the spontaneously hypertensive rat. Am J Hypertens 10:120S-126S

195. Moens AL, Champion HC, Claeys MJ, Tavazzi B, Kaminski PM, Wolin MS, Borgonjon DJ, Van Nassauw L, Haile A, Zviman M, Bedja D, Wuyts FL, Elsaesser RS, Cos P, Gabrielson KL, Lazzarino G, Paolocci N, Timmermans JP, Vrints CJ, Kass DA (2008) High-dose folic acid pretreatment blunts cardiac dysfunction during ischemia coupled to maintenance of highenergy phosphates and reduces postreperfusion injury. Circulation 117:1810-1819. doi:10.1161/CIRCULATIONAHA.107. 725481

196. Moens AL, Ketner EA, Takimoto E, Schmidt TS, O'Neill CA, Wolin MS, Alp NJ, Channon KM, Kass DA (2011) Bi-modal dose-dependent cardiac response to tetrahydrobiopterin in pressure-overload induced hypertrophy and heart failure. J Mol Cell Cardiol. doi:10.1016/j.yjmcc.2011.05.017

197. Moens AL, Leyton-Mange JS, Niu X, Yang R, Cingolani O, Arkenbout EK, Champion HC, Bedja D, Gabrielson KL, Chen J, Xia Y, Hale AB, Channon KM, Halushka MK, Barker N, Wuyts FL, Kaminski PM, Wolin MS, Kass DA, Barouch LA (2009) Adverse ventricular remodeling and exacerbated NOS uncoupling from pressure-overload in mice lacking the beta3-adrenoreceptor. J Mol Cell Cardiol 47:576-585. doi: 10.1016/j.yjmcc.2009.06.005

198. Mohammed SF, Storlie JR, Oehler EA, Bowen LA, Korinek J, Lam CS, Simari RD, Burnett JC Jr, Redfield MM (2011) Variable phenotype in murine transverse aortic constriction. Cardiovasc Pathol. doi:10.1016/j.carpath.2011.05.002
199. Mohapatra B, Jimenez S, Lin JH, Bowles KR, Coveler KJ, Marx JG, Chrisco MA, Murphy RT, Lurie PR, Schwartz RJ, Elliott PM, Vatta M, McKenna W, Towbin JA, Bowles NE (2003) Mutations in the muscle LIM protein and alpha-actinin-2 genes in dilated cardiomyopathy and endocardial fibroelastosis. Mol Genet Metab 80:207-215

200. Molina EJ, Gupta D, Palma J, Torres D, Gaughan JP, Houser S, Macha M (2009) Novel experimental model of pressure overload hypertrophy in rats. J Surg Res 153:287-294. doi:10.1016/ j.jss.2008.03.043

201. Molkentin JD, Lu JR, Antos CL, Markham B, Richardson J, Robbins J, Grant SR, Olson EN (1998) A calcineurin-dependent transcriptional pathway for cardiac hypertrophy. Cell 93:215228

202. Molkentin JD, Robbins J (2009) With great power comes great responsibility: using mouse genetics to study cardiac hypertrophy and failure. J Mol Cell Cardiol 46:130-136. doi:10.1016/ j.yjmcc. 2008.09.002

203. Monnet E, Chachques JC (2005) Animal models of heart failure: what is new? Ann Thorac Surg 79:1445-1453. doi:10.1016/j. athoracsur.2004.04.002

204. Moreau P, Schiffrin EL (2003) Role of endothelins in animal models of hypertension: focus on cardiovascular protection. Can J Physiol Pharmacol 81:511-521. doi:10.1139/y03-015

205. Movsesian MA, Kukreja RC (2011) Phosphodiesterase inhibition in heart failure. Handb Exp Pharmacol 237-249 doi: 10.1007/978-3-642-17969-3_10

206. Muller FU, Kirchhefer U, Begrow F, Reinke U, Neumann J, Schmitz W (2002) Junctional sarcoplasmic reticulum transmembrane proteins in the heart. Basic Res Cardiol 97(Suppl 1): I52-I55

207. Murakami K, Mizushige K, Noma T, Tsuji T, Kimura S, Kohno M (2002) Perindopril effect on uncoupling protein and energy metabolism in failing rat hearts. Hypertension 40:251-255

208. Murata T, Yamawaki H, Yoshimoto R, Hori M, Sato K, Ozaki H, Karaki H (2001) Chronic effect of doxorubicin on vascular endothelium assessed by organ culture study. Life Sci 69:26852695

209. Muth JN, Bodi I, Lewis W, Varadi G, Schwartz A (2001) A $\mathrm{Ca}(2+)$-dependent transgenic model of cardiac hypertrophy: a role for protein kinase Calpha. Circulation 103:140-147

210. Nagano M, Kato M, Nagai M, Yang J (1991) Protective effect of ACE- and kininase-inhibitor on the onset of cardiomyopathy. Basic Res Cardiol 86(Suppl 3):187-195

211. Nagatsu M, Zile MR, Tsutsui H, Schmid PG, DeFreyte G, Cooper Gt, Carabello BA (1994) Native beta-adrenergic support for left ventricular dysfunction in experimental mitral regurgitation normalizes indexes of pump and contractile function. Circulation 89:818-826

212. Nigro V, Okazaki Y, Belsito A, Piluso G, Matsuda Y, Politano L, Nigro G, Ventura C, Abbondanza C, Molinari AM, Acampora D, Nishimura M, Hayashizaki Y, Puca GA (1997) Identification of the Syrian hamster cardiomyopathy gene. Hum Mol Genet 6:601-607

213. Nishio R, Sasayama S, Matsumori A (2002) Left ventricular pressure-volume relationship in a murine model of congestive heart failure due to acute viral myocarditis. J Am Coll Cardiol 40:1506-1514

214. O'Donnell SM, Hansberger MW, Connolly JL, Chappell JD, Watson MJ, Pierce JM, Wetzel JD, Han W, Barton ES, Forrest JC, Valyi-Nagy T, Yull FE, Blackwell TS, Rottman JN, Sherry B, Dermody TS (2005) Organ-specific roles for transcription factor NF-kappaB in reovirus-induced apoptosis and disease. J Clin Invest 115:2341-2350. doi:10.1172/JCI22428

215. Ogata T, Miyauchi T, Sakai S, Takanashi M, Irukayama-Tomobe Y, Yamaguchi I (2004) Myocardial fibrosis and diastolic 
dysfunction in deoxycorticosterone acetate-salt hypertensive rats is ameliorated by the peroxisome proliferator-activated receptoralpha activator fenofibrate, partly by suppressing inflammatory responses associated with the nuclear factor-kappa-B pathway. J Am Coll Cardiol 43:1481-1488. doi:10.1016/j.jacc.2003. 11.043

216. Oudit GY, Crackower MA, Eriksson U, Sarao R, Kozieradzki I, Sasaki T, Irie-Sasaki J, Gidrewicz D, Rybin VO, Wada T, Steinberg SF, Backx PH, Penninger JM (2003) Phosphoinositide 3-kinase gamma-deficient mice are protected from isoproterenol-induced heart failure. Circulation 108:2147-2152. doi: 10.1161/01.CIR.0000091403.62293.2B

217. Ozek C, Zhang F, Lineaweaver WC, Chin BT, Eiman T, Newlin L, Buncke HJ (1998) A new heart failure model in rat by an endto-side femoral vessel anastomosis. Cardiovasc Res 37:236-238

218. Pacher P, Nagayama T, Mukhopadhyay P, Batkai S, Kass DA (2008) Measurement of cardiac function using pressure-volume conductance catheter technique in mice and rats. Nat Protoc 3:1422-1434. doi:10.1038/nprot.2008.138

219. Padmanabhan M, Prince PS (2006) Preventive effect of S-allylcysteine on lipid peroxides and antioxidants in normal and isoproterenol-induced cardiotoxicity in rats: a histopathological study. Toxicology 224:128-137. doi:10.1016/j.tox.2006.04.039

220. Padmanabhan M, Rajadurai M, Prince PS (2008) Preventive effect of S-allylcysteine on membrane-bound enzymes and glycoproteins in normal and isoproterenol-induced cardiac toxicity in male Wistar rats. Basic Clin Pharmacol Toxicol 103:507-513. doi:10.1111/j.1742-7843.2008.00244.x

221. Paradis P, Dali-Youcef N, Paradis FW, Thibault G, Nemer M (2000) Overexpression of angiotensin II type I receptor in cardiomyocytes induces cardiac hypertrophy and remodeling. Proc Natl Acad Sci USA 97:931-936

222. Park SC, Liu-Stratton Y, Medeiros LC, McCune SA, Radin MJ (2004) Effect of male sex and obesity on platelet arachidonic acid in spontaneous hypertensive heart failure rats. Exp Biol Med (Maywood) 229:657-664

223. Patten RD, Hall-Porter MR (2009) Small animal models of heart failure: development of novel therapies, past and present. Circ Heart Fail 2:138-144. doi:10.1161/CIRCHEARTFAILURE. 108.839761

224. Peng X, Chen B, Lim CC, Sawyer DB (2005) The cardiotoxicology of anthracycline chemotherapeutics: translating molecular mechanism into preventative medicine. Mol Interv 5:163171. doi:10.1124/mi.5.3.6

225. Periasamy M, Reed TD, Liu LH, Ji Y, Loukianov E, Paul RJ, Nieman ML, Riddle T, Duffy JJ, Doetschman T, Lorenz JN, Shull GE (1999) Impaired cardiac performance in heterozygous mice with a null mutation in the sarco(endo)plasmic reticulum Ca2+-ATPase isoform 2 (SERCA2) gene. J Biol Chem 274: 2556-2562

226. Pfeffer JM, Pfeffer MA, Fishbein MC, Frohlich ED (1979) Cardiac function and morphology with aging in the spontaneously hypertensive rat. Am J Physiol 237:H461-H468

227. Pfeffer JM, Pfeffer MA, Mirsky I, Braunwald E (1982) Regression of left ventricular hypertrophy and prevention of left ventricular dysfunction by captopril in the spontaneously hypertensive rat. Proc Natl Acad Sci USA 79:3310-3314

228. Pfeffer MA, Pfeffer JM, Fishbein MC, Fletcher PJ, Spadaro J, Kloner RA, Braunwald E (1979) Myocardial infarct size and ventricular function in rats. Circ Res 44:503-512

229. Pleger ST, Remppis A, Heidt B, Volkers M, Chuprun JK, Kuhn M, Zhou RH, Gao E, Szabo G, Weichenhan D, Muller OJ, Eckhart AD, Katus HA, Koch WJ, Most P (2005) S100A1 gene therapy preserves in vivo cardiac function after myocardial infarction. Mol Ther 12:1120-1129. doi:10.1016/j.ymthe.2005.08.002
230. Plestina R, Stoner HB (1972) Pulmonary oedema in rats given monocrotaline pyrrole. J Pathol 106:235-249. doi:10.1002/path. 1711060405

231. Porter CB, Walsh RA, Badke FR, O'Rourke RA (1983) Differential effects of diltiazem and nitroprusside on left ventricular function in experimental chronic volume overload. Circulation 68:685-692

232. Rakieten N, Rakieten ML, Nadkarni MV (1963) Studies on the diabetogenic action of streptozotocin (NSC-37917). Cancer Chemother Rep 29:91-98

233. Redfern CH, Degtyarev MY, Kwa AT, Salomonis N, Cotte N, Nanevicz T, Fidelman N, Desai K, Vranizan K, Lee EK, Coward P, Shah N, Warrington JA, Fishman GI, Bernstein D, Baker AJ, Conklin BR (2000) Conditional expression of a Gi-coupled receptor causes ventricular conduction delay and a lethal cardiomyopathy. Proc Natl Acad Sci USA 97:4826-4831

234. Redfield MM (2000) Epidemiology and pathophysiology of heart failure. Curr Cardiol Rep 2:179-180

235. Reed AL, Tanaka A, Sorescu D, Liu H, Jeong EM, Sturdy M, Walp ER, Dudley SC Jr, Sutliff RL (2011) Diastolic dysfunction is associated with cardiac fibrosis in the senescence-accelerated mouse. Am J Physiol Heart Circ Physiol 301:H824-831. doi: 10.1152/ajpheart.00407.2010

236. Rerup CC (1970) Drugs producing diabetes through damage of the insulin secreting cells. Pharmacol Rev 22:485-518

237. Rizzi E, Castro MM, Prado CM, Silva CA, Fazan R Jr, Rossi MA, Tanus-Santos JE, Gerlach RF (2010) Matrix metalloproteinase inhibition improves cardiac dysfunction and remodeling in 2-kidney, 1-clip hypertension. J Card Fail 16:599-608. doi: 10.1016/j.cardfail.2010.02.005

238. Rockman HA, Chien KR, Choi DJ, Iaccarino G, Hunter JJ, Ross J Jr, Lefkowitz RJ, Koch WJ (1998) Expression of a betaadrenergic receptor kinase 1 inhibitor prevents the development of myocardial failure in gene-targeted mice. Proc Natl Acad Sci USA 95:7000-7005

239. Rockman HA, Ross RS, Harris AN, Knowlton KU, Steinhelper ME, Field LJ, Ross J Jr, Chien KR (1991) Segregation of atrialspecific and inducible expression of an atrial natriuretic factor transgene in an in vivo murine model of cardiac hypertrophy. Proc Natl Acad Sci USA 88:8277-8281

240. Rockman HA, Wachhorst SP, Mao L, Ross J Jr (1994) ANG II receptor blockade prevents ventricular hypertrophy and ANF gene expression with pressure overload in mice. Am J Physiol 266:H2468-H2475

241. Rodriguez-Iturbe B, Quiroz Y, Kim CH, Vaziri ND (2005) Hypertension induced by aortic coarctation above the renal arteries is associated with immune cell infiltration of the kidneys. Am J Hypertens 18:1449-1456. doi:10.1016/j.amjhyper. 2005.05.034

242. Rohrer DK, Chruscinski A, Schauble EH, Bernstein D, Kobilka BK (1999) Cardiovascular and metabolic alterations in mice lacking both beta1- and beta2-adrenergic receptors. J Biol Chem 274:16701-16708

243. Ruiz-Hurtado G, Fernandez-Velasco M, Mourelle M, Delgado C (2007) LA419, a novel nitric oxide donor, prevents pathological cardiac remodeling in pressure-overloaded rats via endothelial nitric oxide synthase pathway regulation. Hypertension 50:1049 1056. doi:10.1161/HYPERTENSIONAHA.107.093666

244. Ruiz P, Witt H (2006) Microarray analysis to evaluate different animal models for human heart failure. J Mol Cell Cardiol 40:13-15. doi:10.1016/j.yjmcc.2005.09.010

245. Ryu JH, Kim IK, Cho SW, Cho MC, Hwang KK, Piao H, Piao S, Lim SH, Hong YS, Choi CY, Yoo KJ, Kim BS (2005) Implantation of bone marrow mononuclear cells using injectable fibrin matrix enhances neovascularization in infarcted myocardium. 
Biomaterials 26:319-326. doi:10.1016/j.biomaterials.2004. 02.058

246. Sah VP, Minamisawa S, Tam SP, Wu TH, Dorn GW 2nd, Ross J Jr, Chien KR, Brown JH (1999) Cardiac-specific overexpression of RhoA results in sinus and atrioventricular nodal dysfunction and contractile failure. J Clin Invest 103:1627-1634. doi: $10.1172 / \mathrm{JCI} 6842$

247. Sakamoto A (2004) Electrical and ionic abnormalities in the heart of cardiomyopathic hamsters: in quest of a new paradigm for cardiac failure and lethal arrhythmia. Mol Cell Biochem 259:183-187

248. Sakamoto A, Abe M, Masaki T (1999) Delineation of genomic deletion in cardiomyopathic hamster. FEBS Lett 447:124-128

249. Sakamoto A, Ono K, Abe M, Jasmin G, Eki T, Murakami Y, Masaki T, Toyo-oka T, Hanaoka F (1997) Both hypertrophic and dilated cardiomyopathies are caused by mutation of the same gene, delta-sarcoglycan, in hamster: an animal model of disrupted dystrophin-associated glycoprotein complex. Proc Natl Acad Sci USA 94:13873-13878

250. Sanbe A, Gulick J, Hanks MC, Liang Q, Osinska H, Robbins J (2003) Reengineering inducible cardiac-specific transgenesis with an attenuated myosin heavy chain promoter. Circ Res 92:609-616. doi:10.1161/01.RES.0000065442.64694.9F

251. Sato Y, Ferguson DG, Sako H, Dorn GW 2nd, Kadambi VJ, Yatani A, Hoit BD, Walsh RA, Kranias EG (1998) Cardiacspecific overexpression of mouse cardiac calsequestrin is associated with depressed cardiovascular function and hypertrophy in transgenic mice. J Biol Chem 273:28470-28477

252. Sato Y, Kiriazis H, Yatani A, Schmidt AG, Hahn H, Ferguson DG, Sako H, Mitarai S, Honda R, Mesnard-Rouiller L, Frank KF, Beyermann B, Wu G, Fujimori K, Dorn GW 2nd, Kranias EG (2001) Rescue of contractile parameters and myocyte hypertrophy in calsequestrin overexpressing myocardium by phospholamban ablation. J Biol Chem 276:9392-9399. doi: 10.1074/jbc.M006889200

253. Satoh S, Ueda Y, Suematsu N, Oyama J, Kadokami T, Sugano M, Yoshikawa Y, Makino N (2003) Beneficial effects of angiotensin-converting enzyme inhibition on sarcoplasmic reticulum function in the failing heart of the Dahl rat. Circ J 67: 705-711

254. Sawyer DB, Fukazawa R, Arstall MA, Kelly RA (1999) Daunorubicin-induced apoptosis in rat cardiac myocytes is inhibited by dexrazoxane. Circ Res 84:257-265

255. Sawyer DB, Peng X, Chen B, Pentassuglia L, Lim CC (2010) Mechanisms of anthracycline cardiac injury: can we identify strategies for cardioprotection? Prog Cardiovasc Dis 53:105113. doi:10.1016/j.pcad.2010.06.007

256. Scheuermann-Freestone M, Freestone NS, Langenickel T, Hohnel K, Dietz R, Willenbrock R (2001) A new model of congestive heart failure in the mouse due to chronic volume overload. Eur J Heart Fail 3:535-543

257. Schiffrin EL (2000) Endothelin: role in experimental hypertension. J Cardiovasc Pharmacol 35:S33-S35

258. Schiffrin EL (2001) Role of endothelin-1 in hypertension and vascular disease. Am J Hypertens 14:83S-89S. doi:S0895706 $10102074 \mathrm{X}$

259. Schlenker EH, Kost CK Jr, Likness MM (2004) Effects of longterm captopril and L-arginine treatment on ventilation and blood pressure in obese male SHHF rats. J Appl Physiol 97:10321039. doi:10.1152/japplphysiol.00255.2004

260. Schmidt-Supprian M, Rajewsky K (2007) Vagaries of conditional gene targeting. Nat Immunol 8:665-668. doi:10.1038/ni 0707-665

261. Schmitt JP, Kamisago M, Asahi M, Li GH, Ahmad F, Mende U, Kranias EG, MacLennan DH, Seidman JG, Seidman CE (2003) Dilated cardiomyopathy and heart failure caused by a mutation in phospholamban. Science 299:1410-1413. doi:10.1126/ science. $1081578299 / 5611 / 1410$

262. Schoental R, Head MA (1955) Pathological changes in rats as a result of treatment with monocrotaline. Br J Cancer 9:229-237

263. Schunkert H, Dzau VJ, Tang SS, Hirsch AT, Apstein CS, Lorell BH (1990) Increased rat cardiac angiotensin converting enzyme activity and mRNA expression in pressure overload left ventricular hypertrophy. Effects on coronary resistance, contractility, and relaxation. J Clin Invest 86:1913-1920. doi:10.1172/ JCI114924

264. Schwarz B, Percy E, Gao XM, Dart AM, Richardt G, Du XJ (2003) Altered calcium transient and development of hypertrophy in beta2-adrenoceptor overexpressing mice with and without pressure overload. Eur J Heart Fail 5:131-136.

265. Schwinger RH, Bohm M, Erdmann E (1990) Evidence against spare or uncoupled beta-adrenoceptors in the human heart. Am Heart J 119:899-904

266. Schwinger RH, Bohm M, Schmidt U, Karczewski P, Bavendiek U, Flesch M, Krause EG, Erdmann E (1995) Unchanged protein levels of SERCA II and phospholamban but reduced $\mathrm{Ca} 2+$ uptake and $\mathrm{Ca}(2+)$-ATPase activity of cardiac sarcoplasmic reticulum from dilated cardiomyopathy patients compared with patients with nonfailing hearts. Circulation 92:3220-3228

267. Seidman JG, Seidman C (2001) The genetic basis for cardiomyopathy: from mutation identification to mechanistic paradigms. Cell 104:557-567

268. Selye H (1942) Production of nephrosclerosis by overdosage with desoxycorticosterone acetate. Can Med Assoc J 47:515-519

269. Shai SY, Harpf AE, Babbitt CJ, Jordan MC, Fishbein MC, Chen J, Omura M, Leil TA, Becker KD, Jiang M, Smith DJ, Cherry SR, Loftus JC, Ross RS (2002) Cardiac myocyte-specific excision of the beta1 integrin gene results in myocardial fibrosis and cardiac failure. Circ Res 90:458-464

270. Shen FM, Xie HH, Ling G, Xu LP, Su DF (2005) Synergistic effects of atenolol and amlodipine for lowering and stabilizing blood pressure in $2 \mathrm{~K} 1 \mathrm{C}$ renovascular hypertensive rats. Acta Pharmacol Sin 26:1303-1308. doi:10.1111/j.1745-7254.2005. 00185.x

271. Shimizu T, Nojiri H, Kawakami S, Uchiyama S, Shirasawa T (2010) Model mice for tissue-specific deletion of the manganese superoxide dismutase gene. Geriatr Gerontol Int 10(Suppl 1):S70-79. doi:10.1111/j.1447-0594.2010.00604.X

272. Shusterman V, Usiene I, Harrigal C, Lee JS, Kubota T, Feldman AM, London B (2002) Strain-specific patterns of autonomic nervous system activity and heart failure susceptibility in mice. Am J Physiol Heart Circ Physiol 282:H2076-H2083. doi: 10.1152/ajpheart.00917.2001

273. Sicard P, Oudot A, Guilland JC, Moreau D, Vergely C, Rochette L (2006) Dissociation between vascular oxidative stress and cardiovascular function in Wistar Kyoto and spontaneously hypertensive rats. Vascul Pharmacol 45:112-121. doi:10.1016/ j.vph.2006.04.001

274. Silberman GA, Fan TH, Liu H, Jiao Z, Xiao HD, Lovelock JD, Boulden BM, Widder J, Fredd S, Bernstein KE, Wolska BM, Dikalov S, Harrison DG, Dudley SC Jr (2010) Uncoupled cardiac nitric oxide synthase mediates diastolic dysfunction. Circulation 121:519-528. doi:10.1161/CIRCULATIONAHA.109.883777

275. Silver DP, Livingston DM (2001) Self-excising retroviral vectors encoding the Cre recombinase overcome Cre-mediated cellular toxicity. Mol Cell 8:233-243

276. Simunek T, Sterba M, Popelova O, Adamcova M, Hrdina R, Gersl V (2009) Anthracycline-induced cardiotoxicity: overview of studies examining the roles of oxidative stress and free cellular iron. Pharmacol Rep 61:154-171

277. Sohal DS, Nghiem M, Crackower MA, Witt SA, Kimball TR, Tymitz KM, Penninger JM, Molkentin JD (2001) Temporally 
regulated and tissue-specific gene manipulations in the adult and embryonic heart using a tamoxifen-inducible Cre protein. Circ Res 89:20-25

278. Stansfield WE, Rojas M, Corn D, Willis M, Patterson C, Smyth SS, Selzman CH (2007) Characterization of a model to independently study regression of ventricular hypertrophy. J Surg Res 142:387-393. doi:10.1016/j.jss.2007.01.037

279. Stock JH, Reller MD, Sharma S, Pavcnik D, Shiota T, Sahn DJ (1997) Transballoon intravascular ultrasound imaging during balloon angioplasty in animal models with coarctation and branch pulmonary stenosis. Circulation 95:2354-2357

280. Sun ZJ, Zhang ZE (2005) Historic perspectives and recent advances in major animal models of hypertension. Acta Pharmacol Sin 26:295-301. doi:10.1111/j.1745-7254.2005.00054.x

281. Surwit RS, Feinglos MN, Rodin J, Sutherland A, Petro AE, Opara EC, Kuhn CM, Rebuffe-Scrive M (1995) Differential effects of fat and sucrose on the development of obesity and diabetes in C57BL/6J and A/J mice. Metabolism 44:645-651

282. Sussman MA, Welch S, Walker A, Klevitsky R, Hewett TE, Price RL, Schaefer E, Yager K (2000) Altered focal adhesion regulation correlates with cardiomyopathy in mice expressing constitutively active rac1. J Clin Invest 105:875-886. doi: 10.1172/JCI8497

283. Suzuki M, Carlson KM, Marchuk DA, Rockman HA (2002) Genetic modifier loci affecting survival and cardiac function in murine dilated cardiomyopathy. Circulation 105:1824-1829

284. Szenczi O, Kemecsei P, Holthuijsen MF, van Riel NA, van der Vusse GJ, Pacher P, Szabo C, Kollai M, Ligeti L, Ivanics T (2005) Poly(ADP-ribose) polymerase regulates myocardial calcium handling in doxorubicin-induced heart failure. Biochem Pharmacol 69:725-732. doi:10.1016/j.bcp.2004.11.023

285. Takahashi S, Denvir MA, Harder L, Miller DJ, Cobbe SM, Kawakami M, MacFarlane NG, Okabe E (1998) Effects of in vitro and in vivo exposure to doxorubicin (adriamycin) on caffeine-induced $\mathrm{Ca} 2+$ release from sarcoplasmic reticulum and contractile protein function in 'chemically-skinned' rabbit ventricular trabeculae. Jpn J Pharmacol 76:405-413

286. Takeishi Y, Ping P, Bolli R, Kirkpatrick DL, Hoit BD, Walsh RA (2000) Transgenic overexpression of constitutively active protein kinase $\mathrm{C}$ epsilon causes concentric cardiac hypertrophy. Circ Res 86:1218-1223

287. Takemura G, Fujiwara H (2007) Doxorubicin-induced cardiomyopathy from the cardiotoxic mechanisms to management. Prog Cardiovasc Dis 49:330-352. doi:10.1016/j.pcad.2006.10. 002

288. Takemura G, Miyata S, Kawase Y, Okada H, Maruyama R, Fujiwara H (2006) Autophagic degeneration and death of cardiomyocytes in heart failure. Autophagy 2:212-214

289. Takenaka H, Kihara Y, Iwanaga Y, Onozawa Y, Toyokuni S, Kita T (2006) Angiotensin II, oxidative stress, and extracellular matrix degradation during transition to $\mathrm{LV}$ failure in rats with hypertension. J Mol Cell Cardiol 41:989-997. doi:10.1016/j. yjmcc.2006.07.019

290. Takimoto E, Champion HC, Li M, Belardi D, Ren S, Rodriguez ER, Bedja D, Gabrielson KL, Wang Y, Kass DA (2005) Chronic inhibition of cyclic GMP phosphodiesterase 5A prevents and reverses cardiac hypertrophy. Nat Med 11:214-222. doi:10. 1038/nm1175

291. Taniyama Y, Walsh K (2002) Elevated myocardial Akt signaling ameliorates doxorubicin-induced congestive heart failure and promotes heart growth. J Mol Cell Cardiol 34:1241-1247

292. Teerlink JR, Pfeffer JM, Pfeffer MA (1994) Progressive ventricular remodeling in response to diffuse isoproterenol-induced myocardial necrosis in rats. Circ Res 75:105-113

293. Terrand J, Xu B, Morrissy S, Dinh TN, Williams S, Chen QM (2011) p21(WAF1/Cip1/Sdi1) knockout mice respond to doxorubicin with reduced cardiotoxicity. Toxicol Appl Pharmacol. doi:10.1016/j.taap.2011.08.024

294. Toischer K, Rokita AG, Unsold B, Zhu W, Kararigas G, Sossalla S, Reuter SP, Becker A, Teucher N, Seidler T, Grebe C, Preuss L, Gupta SN, Schmidt K, Lehnart SE, Kruger M, Linke WA, Backs J, Regitz-Zagrosek V, Schafer K, Field LJ, Maier LS, Hasenfuss G (2010) Differential cardiac remodeling in preload versus afterload. Circulation 122:993-1003. doi:10.1161/ CIRCULATIONAHA.110.943431

295. Tomlinson KC, Gardiner SM, Hebden RA, Bennett T (1992) Functional consequences of streptozotocin-induced diabetes mellitus, with particular reference to the cardiovascular system. Pharmacol Rev 44:103-150

296. Towbin JA, Bowles NE (2002) The failing heart. Nature 415: 227-233. doi:10.1038/415227a

297. Tsuji T, Del Monte F, Yoshikawa Y, Abe T, Shimizu J, Nakajima-Takenaka C, Taniguchi S, Hajjar RJ, Takaki M (2009) Rescue of Ca2+ overload-induced left ventricular dysfunction by targeted ablation of phospholamban. Am J Physiol Heart Circ Physiol 296:H310-317. doi:10.1152/ajpheart.00975. 2008

298. Ungerer M, Parruti G, Bohm M, Puzicha M, DeBlasi A, Erdmann E, Lohse MJ (1994) Expression of beta-arrestins and betaadrenergic receptor kinases in the failing human heart. Circ Res $74: 206-213$

299. Usui S, Yao A, Hatano M, Kohmoto O, Takahashi T, Nagai R, Kinugawa K (2006) Upregulated neurohumoral factors are associated with left ventricular remodeling and poor prognosis in rats with monocrotaline-induced pulmonary arterial hypertension. Circ J 70:1208-1215

300. Van den Berg DT, de Kloet ER, de Jong W (1994) Central effects of mineralocorticoid antagonist RU-28318 on blood pressure of DOCA-salt hypertensive rats. Am J Physiol 267:E927-E933

301. Van den Bergh A, Flameng W, Herijgers P (2006) Type II diabetic mice exhibit contractile dysfunction but maintain cardiac output by favourable loading conditions. Eur J Heart Fail 8:777-783. doi:10.1016/j.ejheart.2006.03.001

302. van den Meiracker AH (2002) Endothelins and venous tone in DOCA-salt hypertension. J Hypertens 20:587-589

303. Vicart P, Caron A, Guicheney P, Li Z, Prevost MC, Faure A, Chateau D, Chapon F, Tome F, Dupret JM, Paulin D, Fardeau M (1998) A missense mutation in the alphaB-crystallin chaperone gene causes a desmin-related myopathy. Nat Genet 20:92-95. doi:10.1038/1765

304. Wakasaki H, Koya D, Schoen FJ, Jirousek MR, Ways DK, Hoit BD, Walsh RA, King GL (1997) Targeted overexpression of protein kinase $\mathrm{C}$ beta2 isoform in myocardium causes cardiomyopathy. Proc Natl Acad Sci USA 94:9320-9325

305. Wakisaka Y, Niwano S, Niwano H, Saito J, Yoshida T, Hirasawa S, Kawada H, Izumi T (2004) Structural and electrical ventricular remodeling in rat acute myocarditis and subsequent heart failure. Cardiovasc Res 63:689-699. doi:10.1016/j.cardi ores.2004.04.020

306. Wang QD, Bohlooly YM, Sjoquist PO (2004) Murine models for the study of congestive heart failure: Implications for understanding molecular mechanisms and for drug discovery. J Pharmacol Toxicol Methods 50:163-174. doi:10.1016/j.vasen. 2004.05.005

307. Wang X, Ren B, Liu S, Sentex E, Tappia PS, Dhalla NS (2003) Characterization of cardiac hypertrophy and heart failure due to volume overload in the rat. J Appl Physiol 94:752-763. doi: 10.1152/japplphysiol.00248.200294/2/752

308. Wang X, Sentex E, Saini HK, Chapman D, Dhalla NS (2005) Upregulation of beta-adrenergic receptors in heart failure due to volume overload. Am J Physiol Heart Circ Physiol 289:H151159. doi:10.1152/ajpheart.00066.2005 
309. Weinberg EO, Schoen FJ, George D, Kagaya Y, Douglas PS, Litwin SE, Schunkert H, Benedict CR, Lorell BH (1994) Angiotensin-converting enzyme inhibition prolongs survival and modifies the transition to heart failure in rats with pressure overload hypertrophy due to ascending aortic stenosis. Circulation 90:1410-1422

310. Werchan PM, Summer WR, Gerdes AM, McDonough KH (1989) Right ventricular performance after monocrotalineinduced pulmonary hypertension. Am J Physiol 256:H1328H1336

311. West MB, Rokosh G, Obal D, Velayutham M, Xuan YT, Hill BG, Keith RJ, Schrader J, Guo Y, Conklin DJ, Prabhu SD, Zweier JL, Bolli R, Bhatnagar A (2008) Cardiac myocyte-specific expression of inducible nitric oxide synthase protects against ischemia/reperfusion injury by preventing mitochondrial permeability transition. Circulation 118:1970-1978. doi: 10.1161/CIRCULATIONAHA.108.791533

312. Wettschureck N, Rutten H, Zywietz A, Gehring D, Wilkie TM, Chen J, Chien KR, Offermanns S (2001) Absence of pressure overload induced myocardial hypertrophy after conditional inactivation of Galphaq/Galpha11 in cardiomyocytes. Nat Med 7:1236-1240. doi:10.1038/nm1101-1236

313. Wilson KM, Sumners C, Hathaway S, Fregly MJ (1986) Mineralocorticoids modulate central angiotensin II receptors in rats. Brain Res 382:87-96

314. Wood P, Piran S, Liu PP (2011) Diastolic heart failure: progress, treatment challenges, and prevention. Can J Cardiol 27:302310. doi:10.1016/j.cjca.2011.02.008

315. Wu JC, Nasseri BA, Bloch KD, Picard MH, Scherrer-Crosbie M (2003) Influence of sex on ventricular remodeling after myocardial infarction in mice. J Am Soc Echocardiogr 16:11581162. doi:10.1067/S0894-7317(03)00648-5

316. Xiao CY, Chen M, Zsengeller Z, Li H, Kiss L, Kollai M, Szabo C (2005) Poly(ADP-Ribose) polymerase promotes cardiac remodeling, contractile failure, and translocation of apoptosisinducing factor in a murine experimental model of aortic banding and heart failure. J Pharmacol Exp Ther 312:891-898. doi:10.1124/jpet.104.077164

317. Xin HB, Senbonmatsu T, Cheng DS, Wang YX, Copello JA, Ji GJ, Collier ML, Deng KY, Jeyakumar LH, Magnuson MA, Inagami T, Kotlikoff MI, Fleischer S (2002) Oestrogen protects FKBP12.6 null mice from cardiac hypertrophy. Nature 416:334 338. doi:10.1038/416334a

318. Yamada T, Matsumori A, Wang WZ, Ohashi N, Shiota K, Sasayama S (1999) Apoptosis in congestive heart failure induced by viral myocarditis in mice. Heart Vessels 14:29-37
319. Yamori Y (1991) Overview: studies on spontaneous hypertension-development from animal models toward man. Clin Exp Hypertens A 13:631-644

320. Yang S, Su L, Wang Z, Liu Z, Kang Y, Lei J (2011) Comparative study on repairing rabbit radius segmental defects with two different proportions of chitosan combined with allogeneic morselized bone. Zhongguo Xiu Fu Chong Jian Wai Ke Za Zhi 25:877-883

321. Yano M, Kobayashi S, Kohno M, Doi M, Tokuhisa T, Okuda S, Suetsugu M, Hisaoka T, Obayashi M, Ohkusa T, Matsuzaki M (2003) FKBP12.6-mediated stabilization of calcium-release channel (ryanodine receptor) as a novel therapeutic strategy against heart failure. Circulation 107:477-484

322. Yoo B, Lemaire A, Mangmool S, Wolf MJ, Curcio A, Mao L, Rockman HA (2009) Beta1-adrenergic receptors stimulate cardiac contractility and CaMKII activation in vivo and enhance cardiac dysfunction following myocardial infarction. Am J Physiol Heart Circ Physiol 297:H1377-1386. doi:10.1152/ajp heart.00504.2009

323. Yoshida M, Ohkusa T, Nakashima T, Takanari H, Yano M, Takemura G, Honjo H, Kodama I, Mizukami Y, Matsuzaki M (2011) Alterations in adhesion junction precede gap junction remodelling during the development of heart failure in cardiomyopathic hamsters. Cardiovasc Res 92:95-105. doi:10.1093/ $\mathrm{cvr} / \mathrm{cvr} 182$

324. Zbinden G, Bagdon RE (1963) Isoproterenol-induced heart necrosis, an experimental model for the study of Angina Pectoris and Myocardial Infarct. Rev Can Biol 22:257-263

325. Zbinden G, Moe RA (1969) Pharmacological studies on heart muscle lesions induced by isoproterenol. Ann N Y Acad Sci 156:294-308

326. Zhou YY, Song LS, Lakatta EG, Xiao RP, Cheng H (1999) Constitutive beta2-adrenergic signalling enhances sarcoplasmic reticulum $\mathrm{Ca} 2+$ cycling to augment contraction in mouse heart. J Physiol 521(Pt 2):351-361

327. Zile MR, Brutsaert DL (2002) New concepts in diastolic dysfunction and diastolic heart failure: Part I: diagnosis, prognosis, and measurements of diastolic function. Circulation 105:13871393

328. Zisa D, Shabbir A, Mastri M, Suzuki G, Lee T (2009) Intramuscular VEGF repairs the failing heart: role of host-derived growth factors and mobilization of progenitor cells. Am J Physiol Regul Integr Comp Physiol 297:R1503-1515. doi:10. 1152/ajpregu.00227.2009 